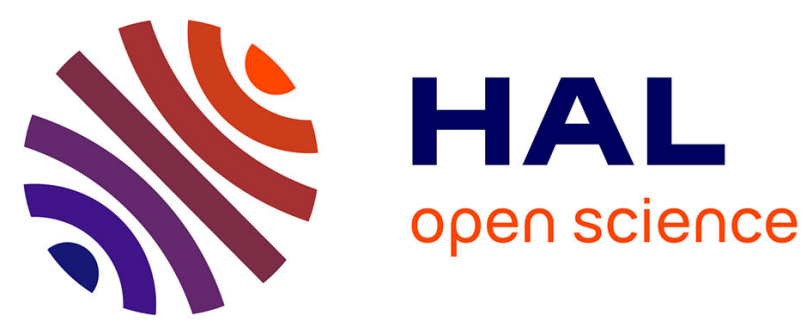

\title{
THOMAS AQUINAS AS AUTHORITY AND THE SUMMA THEOLOGIAE AS AUCTORITAS IN THE LATE MIDDLE AGES
}

Monica Brinzei, Chris Schabel

\section{- To cite this version:}

Monica Brinzei, Chris Schabel. THOMAS AQUINAS AS AUTHORITY AND THE SUMMA THEOLOGIAE AS AUCTORITAS IN THE LATE MIDDLE AGES. Summistae. The Commentary Tradition on Thomas Aquinas's Summa Theologiae from the 15th to the 17th Centuries)„, 2021. hal03468808

\section{HAL Id: hal-03468808 \\ https://hal.science/hal-03468808}

Submitted on 7 Dec 2021

HAL is a multi-disciplinary open access archive for the deposit and dissemination of scientific research documents, whether they are published or not. The documents may come from teaching and research institutions in France or abroad, or from public or private research centers.
L'archive ouverte pluridisciplinaire HAL, est destinée au dépôt et à la diffusion de documents scientifiques de niveau recherche, publiés ou non, émanant des établissements d'enseignement et de recherche français ou étrangers, des laboratoires publics ou privés. 


\title{
Thomas Aquinas as Authority and the Summa Theologiae as AUCtoritas
}

\section{in the Late Middle Ages}

\author{
MONICA BRÎNZEI - CHRIS SCHABEL \\ (CNRS-IRHT, Paris) - (University of Cyprus)
}

In the early 1330s in Tabriz, Persia, in modern Iraq, the Franciscan Friar Hugolino remarked that, on account of Thomas Aquinas' position on the poverty of Christ, he was a heretic, because his determination went against the Bible and the saints, "and many Friars Minor were ready to prove the contrary". Hugolino admitted that Aquinas had "written well on many other matters, but in this he erred disgracefully. The things they preached about him on his feast day, moreover, were lies, because God never revealed a miracle for him". In the Minorite convent of Tabriz, a Venetian heard Friar Luigi claim that Friar Giorgio had asserted that Pope John XXII was a heretic and should not have canonized Aquinas. When the Venetian asked why the pope made him a saint then, Luigi responded, “I don't know why he canonized him, but I know that some people told him before the canonization, 'Be careful, Lord Pope, of what you do, because you will always be blamed for canonizing a heretic'”. Friar Luigi and Friar Filippo agreed with Friar Giorgio, whose opinion about Aquinas the Venetian had also heard first hand ${ }^{1}$.

Granted, the opinion of some Spiritual Franciscans living in the jurisdiction of the Dominican Bishop William of Tabriz as recorded in an inquisition conducted in the local Dominican convent is likely to be extreme, but we present it to show that Thomas Aquinas was by no means a universal authority in the late Middle Ages, even after his canonization, which was anything but a process devoid of political meaning. Indeed, in a mid-14th century Parisian

\footnotetext{
${ }^{1}$ Città del Vaticano, Archivio Segreto Vaticano, Reg. Aven. 54, ff. 530r-534v, at f. 531r (Hugolino): "Postea dixit de beato Thoma, quia fecerat et determinaverat illam questionem de paupertate Christi, quod erat similiter excommunicatus et haereticus, quia fecerat illam determinationem contra dicta sacrae scripturae et sanctorum, et quod multi Fratres Minores erant parati probare contrarium. Et licet beatus Thomas multa alia bene scripserit, tamen in hoc turpiter erravit. Et illa que fuerunt praedicata de eo in festo suo fuerunt mendacia, quia numquam pro eo Deus hostendit miraculum"; f. 531v (Giorgio): "Ex quibus concludebat quod dominus papa ceciderat a potestate sua et erat haereticus, nec erat sibi oboediendum, et quod beatus Thomas canonizatus per eum erat haereticus. Et cum dictus dominus Philippus respondisset, 'Quare ergo canonizavit eum, si erat haereticus?', respondit, 'Nescio quare canonizavit eum, sed scio quod quidam dixerunt sibi ante canonizationem, caveatis, domine papa, quid facitis, quia semper improperabitur vobis quod canonizastis unum haereticum'. Et omnia supradicta frater Ludovicus et frater Philippus de Montearcino, qui erat etiam praesens, affirmabant et consentiebant eidem fratri Georgio"; f. 532r (Giorgio): "Concludens ex hoc et aliis quod erat haereticus, et beatus Thomas de Aquino per eum canonizatus similiter". The text has also been edited in GoluBovich (1919), pp. 436-51, although he incorrectly cites the folios as 530r-543v, an error repeated in later literature, which therefore sometimes claims that Golubovich published only a partial transcription, although it is complete.
} 
manuscript of the anti-mendicant Roman de la Rose, it appears that the female illustrator, Jeanne de Montbaston, has depicted the deceptive Faus Semblant as Thomas Aquinas, the hypocritically fat Dominican ${ }^{2}$. More moderate voices, like that of the Franciscan Andrew of Novocastro, bachelor of theology at Paris in the 1360s, could still point out that, "although [Aquinas] has been canonized, his teachings have not been canonized; rather they contain many errors" 3 . Andreas then concluded his entire treatise on the Immaculate Conception of the Virgin by appealing to the authority of "St Thomas Aquinas," who contradicted himself, supporting the doctrine in one place and rejecting it in another: "Look there! These are his own words!"4.

Still, no matter what the various attitudes to him were in the late Middle Ages, Aquinas was a thinker whose ideas were always to be reckoned with. While most philosophers are ignored and some are criticized, only an extremely select few become the subject of commentary. The process by which the commentary tradition on Thomas Aquinas' STh evolved was slow, but already in the century after his death his writings and his main Summa in particular became the focus of special attention. Aquinas' towering role as teaching doctor of the Dominican Order meant that theologians inside and outside the Order of Friars Preacher found it necessary to interpret his teachings and to point out and, for his supporters, reconcile contradictions in his œuvre, whether apparent or real.

Our paper is in two parts. First we will look at the 'contradiction' literature, the lists of issues where Aquinas was seen to have held one doctrine in one work and a contradictory thesis in another. Using the example of the Cistercian Conrad of Ebrach, who debated with Dominican Thomists around 1370, we can see what role the indication of these at least apparent inconsistencies played in theological debate as Aquinas slowly rose from an important thinker of the recent past to a timeless authority on the level of Augustine. Second, we will look at how Aquinas' article on divine foreknowledge (I, q. 14, art. 13) became a text that required interpretation. Rather than simply accept or reject his stance, with or without arguments, theologians in the decades and centuries after Aquinas first had to determine what he meant.

\footnotetext{
${ }^{2}$ STINSON 2012, pp. 476-81.

${ }^{3}$ ANDREAS De Novo CASTRO, Tractatus de conceptione Virginis gloriosae, art. 9, ed. SzABÒ (1954), p. 208, 11. 15-6: "Respondeo quod, quamvis sit canonizatus, tamen sua doctrina non est canonizata, immo continet plures errores".

${ }^{4}$ Andreas de Novo Castro, Tractatus de conceptione Virginis gloriosae, art. 15, ed. SzABÒ (1954), p. 232, 11. 9-17: "Item, hanc opinionem approbat sanctus Thomas de Aquino, I Sententiarum, dist. $<44>$ [24], in quaestione utrum Deus potuit facere mundum meliorem; in solutione cuiusdam argumenti dicit assertive quod beata Virgo fuit immunis ab originali peccato. Sed dist. 3 III libri dicit oppositum. Vide ibi. Haec sunt verba sua. Explicit Tractatus Andreae de Novo Castro, Ordinis Minorum, de Conceptione Virginis gloriosae, cui laus debetur in saecula saeculorum. Amen".
} 


\section{Saint Thomas Contradicts Himself}

The tense relations and intense polemics between the Franciscans and Dominicans in the first half of the 14th century are a prevalent theme in medieval studies ${ }^{5}$. Yet the debate over the Doctor Angelicus' doctrine and its proper interpretation extended beyond the members of the two orders. In the early decades following the Black Death, we find some examples of other authors who joined the fray. The Principia of the Cistercian Conrad of Ebrach provide a clear case of the criticism that Saint Thomas' teaching was full of contradictions.

Conrad may be unique in the tradition of the Sentences commentaries in that there is evidence that he studied or lectured on Lombard's text at four different universities ${ }^{6}$. From Paris to Vienna via Bologna and Prague, our Bernardine was a dynamic bachelor and master, involved in the organization of the curriculum of some of these universities. We do not have abundant information about his academic travels, but some details help confirm his presence in each of these studia. A rare biographical statement from the eulogy written by Augustinian Hermit John of Retz, a theologian active at Vienna at Conrad's death there in 1399, confirms Conrad's presence in each of the four universities: "In the time of his youth he moved to the studium of Paris, next [he read] the Sentences and the Bible at the University of Bologna, after that he reigned for many years over the doctrinal chair and schools of Prague and Vienna ${ }^{7}$ ". Retz does not state that Conrad was first sententiarius at Paris or Bologna, but other evidence suggests that he lectured on the Sentences in 1368-69 in Bologna, where he was already attested as master in the spring of $1371^{8}$. Conrad was connected to the Augustinian Hermit Hugolino of Orvieto, who was in Bologna in order to organize the new Faculty of Theology. John of Retz remarks in his eulogy: "This is clear in his Lectura on the books of the Sentences, which he faithfully, clearly, and precisely explained, and he reduced to clear and lucid style the obscure and elevated sayings of Master Hugolino of venerable memory, whose disciple he was in

\footnotetext{
${ }^{5}$ See recently Friedman 2013 and PhD dissertation of RoBIN FABRE 2013.

${ }^{6}$ LAUTERER 1962, pp. 27-9; SCHABEL-BRîNZEI-MAGA 2015, pp. 21-9; BRîNZEI-Schabel 2018, pp. 455-7.

7 Iohannes De ReTz, Collatio in exequiis magistri Conradi de Ebraco Ordinis Cysterciensis, ms. Rein, Stiftsbibliothek, Cod. 67, f. 117r: "Nam tempore suae iuventutis ad Parysiense studium se transtulit, tandem in Universitate Bononiensi Sententias et Bybliam < legit>, post hoc Pragae et Wyennae kathedram doctoralem et scolas pluribus aniis rexit". Cf. LAUTERER 1962, pp. 23 and 32; there is an edition in LAUTERER 1961.

${ }^{8}$ EHRLE 1932, p. 103; ZuMKeller 1948, pp. 25-8; LAUTERER 1962, pp. 17-8, 27-9, 83-5; MARCOLINO 1990, 379 83.
} 
Bologna. And he published this in the University of Prague"9. Manuscript Krakow, Biblioteka Jagiellońska 1279, confirms his lectures in Prague: "And in this are ended the questions on book IV of the Sentences of the reverend master Conrad of Ebrach, doctor of holy theology, read out (pronunciate) in Prague in the schools of St Bernard, finished on the vigil of St Bernard [19 August] in 1377"10. In Vienna, where he is attested after 1384, our Cistercian was entrusted with another mission, participating in the redaction of the statutes of the Faculty of Theology, and together with Andrew of Heiligenkreuz Conrad belongs to the first generation of professors in the Cistercian College of St Nicholas ${ }^{11}$. The manuscript tradition of Conrad's Sentences commentary seems to split into two branches, bearing traces of disparate but contemporary academic worlds, with evidence for a praeparatio Parisiensis, a lectura Bononiensis, and then a lectura Pragensis ${ }^{12}$; like the seculars Henry of Langenstein and Henry Totting of Oyta, Conrad probably re-read his commentary at the new University of Vienna-a lectura viennensi ${ }^{13}$. At first glance, these texts can be characterized as sharing the same doctrine, with the majority of the arguments simply rewritten or expressed in different words. The core of Conrad's text is therefore valuable as reflective of several academic milieux in the late 14th century.

Conrad's Bologna Principia contain the largest cluster of his references to Thomas Aquinas ${ }^{14}$. The Principia stem from a scholarly exercise that took place over the academic year among fellow bachelors of theology at the beginning of the lectures on each book of the Sentences ${ }^{15}$. Unlike the remainder of Sentences commentaries, therefore, written Principia are often composed along the lines of a disputatio. Since the debate was not conducted under the authority of a master, moreover, the opponents were free during the confrontation to attack each other and to defend their positions, thus expressing their preferred manner of analyzing a problem. As was customary, in his Principia Conrad debated with socii from different religious

\footnotetext{
${ }^{9}$ IOHANNES DE RETZ, Collatio, ms. Rein 67, f. 116v: "Quod utique patet [pater (Conradus) Lauterer] in sua Lectura super libros Sententiarum quam fideliter et clare et enucleate expressit, et dicta obscura et alta venerandae memoriae magistri Hugolini, cuius discipulus Bononiae extitit, ad stilum clarum et ludicum reduxit, quam [que Lauterer] in Pragensi Universitate publicavit”. Cf. LAUTERER 1962, pp. 68, 103, 111.

${ }^{10}$ CONRADUS DE EBRACHO, In IV Sent., ms. Krakow, Biblioteka Jagiellońska 1279, f. 224ra: "Et in hoc terminantur quaestiones super quarto libro Sententiarum reverendi magistri Conradi d'Ebraco doctoris sacrae theologiae pronunciatae Pragae in scolis sancti Bernardi finite in vigilia sancti Bernardi 1377’.

${ }^{11}$ SCHACHENMAYR 2012, pp. 152 and 155.

${ }^{12}$ SCHABEL 2014, pp. 144 and 177-82; SCHABEL-BRÎNZEI-MAGA 2015, pp. 21-30; BRÎNZEI-SCHABEL 2018 , pp. 445-8.

${ }^{13}$ For Langenstein and Oyta at Vienna, see SHANK 1988, pp. 89 and 127-9.

${ }^{14}$ BRÎNZEI-SCHABEL 2018, p. 459.

${ }^{15}$ See now DUBA 2017.
} 
orders, but he mentions only an unnamed Augustinian and two Dominicans, Bartholomew and Peter of Ragena/Aragonia. The most animated discussion was definitely with his Dominican socii, the only witness to whose words comes from the debate with Conrad.

Conrad's first Principium is divided into three articles, the first of which provides proof of a confrontation between the Cistercian Conrad and one of his Dominican socii, called each time reverendus bachalarius. The topic of the debate is rather metaphysical and philosophical, focusing on the problem of the necessity and contingency of created beings. First Conrad proves a corollary that "no creature is simply and absolutely necesse esse":

1. No necesse esse can begin to exist or cease to exist; every creature begins to exist and can cease to exist; therefore...

2. No simply and absolutely necesse esse is contingent; every creature is contingent; therefore...

3. If any creatures were necesse esse, it follows according to the position of said socius that there would be many simply and absolutely necesse esse, which is false...

4. A creature is simply and absolutely necesse esse, so a simply and absolutely necesse esse depends on God [...]. The consequent is false...

5. A creature is simply and absolutely necesse esse, so it is impossible for it not to exist. The consequent is false... ${ }^{16}$.

Conrad's second corollary is that "there is only one simply and absolutely necesse esse, which is God, and every other being aside from Him is not necesse esse, but merely contingent" 17 . Thus Conrad maintains that the existence of God (Deum esse) is the only being (ens) that is completely and absolutely necessary, since God exists independently of everything else and is not produced by any cause. All other beings, or creatures, depend on God because they are brought into being by God. Since one of the main characteristics of necessity is not to be related

\footnotetext{
${ }^{16}$ CONRAdus DE EBracho, Principium I, art. 1, ed. M. BRÎNZEI, forthcoming: "Nulla creatura est simpliciter et absolute necesse esse... 1. nullum necesse esse potest incipere esse vel desinere; quaelibet creatura incipit esse et potest desinere; igitur... 2. nullum simpliciter et absolute necesse est contingens; sed quaelibet creatura est contingens; igitur... 3. si aliquae creaturae forent necesse esse, sequitur secundum positionem dicti socii quod plura essent simpliciter et absolute necesse esse, quod est falsum... 4. creatura est simpliciter et absolute necesse esse, igitur simpliciter et absolute necesse esse dependet a Deo [...]. Consequens autem est falsum... 5. aliqua creatura est simpliciter et absolute necesse esse, igitur eandem est impossibile non esse. Consequens est falsum...".

${ }^{17}$ Ibid.: "Ex quo infero ulterius quod est unum solum simpliciter et absolute necesse esse quod est Deus, et omne aliud ens circa ipsum non est necesse esse, sed mere contingens [...]".
} 
to any cause in order to exist, and since all creatures in the world are produced by God, therefore they cannot be necessary but only contingent beings ${ }^{18}$.

Conrad maintains that his socius is of the opposite opinion, and our Cistercian lists eight conclusions that he claims his socius defended in his first Principium:

1. Art. 1, conc. 4: a necesse esse is able not to exist.

2. Art. 2, conc. 2: an absolutely necesse esse can have a cause of its being.

3. Art. 2, conc. 3: it is not repugnant for a necesse esse to be conserved [in being] by something else.

4. Art. 3, conc. 2: a simply necesse esse can last precisely for an instant of time.

5. Art. 4, conc. 1: every simply demonstrable proposition is an absolutely and simply necesse esse.

6. Art. 4, conc. 2: a celestial body is a simply necesse esse.

7. Art. 4, conc. 3: an angel and a soul are simply necesse esse.

8. Art. 4, conc. 4: there is some necesse esse besides God $^{19}$.

While Conrad claims that only God is a simply and absolutely necessary being, his socius apparently asserts that other creatures share this with God. According to this socius, celestial bodies, angels, and rational souls are necesse esse. Conrad declares many times that his opponent maintains the thesis that there are some beings other than God Himself that are absolutely and simply necessary, the reason being that they are absolutely and necessarily attached to God. Conrad adds that his socius defends this different metaphysical perspective of the necessity of being in direct conformity with Thomas Aquinas' doctrine. More precisely, the source of this doctrine is said to be Aquinas' $S c G$ II, chapter 29 (recte 30), to which Conrad's socius refers several times ${ }^{20}$.

\footnotetext{
${ }^{18}$ Ibid.: "Sic igitur patet corollarium meum esse verum, ut puto, scilicet quod nulla creatura est simpliciter et absolute necesse esse. Ex quo infero ulterius quod est unum solum simpliciter et absolute necesse esse quod est Deus, et omne aliud ens citra ipsum non est necesse esse, sed mere contingens".

${ }^{19}$ Ibid.: "Primo arguit pro conclusione quarta primi sui articuli, quae ponit necesse esse posse non esse [...]. Secundo arguit pro secunda sua conclusione secundi articuli, quae dicit quod absolute necesse esse potest habere causam sui esse [...]. Tertio arguitur pro conclusione tertia eiusdem articuli, quae ponit quod necesse esse non repugnat ab alio conservari [...]. Quarto arguit pro conclusione secunda tertii sui articuli, quae est quod simpliciter necesse esse potest durare praecise per instans temporis [...]. Quinto arguit pro conclusione prima quarti articuli, quae dicit quod quaelibet propositio simpliciter demonstrabilis est absolute et simpliciter et necesse esse [...]. Sexto arguit pro conclusione secunda eiusdem articuli, quae est quod corpus caeleste est simpliciter necesse esse [...]. Septimo arguit pro tertia conclusione eiusdem articuli, quae dicit quod angelus et anima sunt simpliciter necesse esse [...]. Octavo et ultimo arguit pro conclusione quarta eiusdem articuli, quae est quod praeter Deum est aliquod necesse esse $[\ldots]$ ".

${ }^{20}$ For example, in support of conclusions 3 and 8 the Dominican socius quotes Aquinas directly; ibid.: "Probat assumptum et consequentiam per beatum Thomam Contra Gentiles, libro 2, capitulo 29. Confirmatur per eum, quia angeli et caelum sunt simpliciter necesse esse et tamen eis non repugnat ab alio conservari, igitur". "Et allegat pro isto beatum Thomam Contra Gentiles, libro 2, capitulo 29, quem dicit istam conclusionem assentire".
} 
In order to defend his position and reject that of his socius, one of Conrad's strategies is to attack the authority of the source, because, as our Cistercian remarks later in his third Principium, "the reverend bachelor holds that the sayings of Blessed Thomas are true in part and in whole" 21 . First, according to Conrad, an equally renowned doctor, namely Henry of Ghent, holds that the conclusion based on Aquinas is false and simply impossible, and indeed entails a contradiction ${ }^{22}$. Second, wanting to be more persuasive and to convince his socius and eventually his audience that the view of Sanctus Thomas is false, Conrad compiles a list of ten contradictions $^{23}$, which are not related to the topic of the debate, but which point out that Aquinas constantly contradicted himself on various subjects. Conrad's list is composed as a Concordance between Aquinas' Sentences commentary and the STh, and the subjects are as follows $^{24}$ :

1. The distinction between esse et essentia;

2. The merit of acts of charity or love and the increase of grace thereby;

3. The nature of the dove in which the Holy Spirit appeared;

\footnotetext{
${ }^{21}$ Ibid.: "[...] quia reverendus bachalarius tenet quod dicta beati Thomae sunt vera in parte et in toto".

${ }^{22}$ Ibid.: "Ad beatum Thomam, dico quod quidam non minus reputatus doctor, salva sanctitate dicti doctoris, tenet assertive quod dicta conclusio sit falsa et simpliciter impossibilis, immo ostendit quod implicat contradictionem, et est doctor Solemnis, VIII Quolibeto, q. 9, per totum".

${ }^{23}$ Ibid.: "Nam primo apparet mihi quod ex dictis suis possit huiusmodi contradictionis oppositum demonstrari". This list of 10 contradictions is not present in all the manuscripts.

${ }^{24}$ Ibid.: "Primo dicit in Ia parte Summae, q. 44, art. 1 in corpore quaestionis, "quod omnia alia a Deo non sint suum esse'. Et quod cuiuslibet creaturae essentia et esse differunt. Item, ut secundo dicit idem I Sent., dist. 17, art. 8, quod non quolibet actu caritatis homo meretur caritatis augmentum; et in IIa IIae, q. 24, a. 6 dicit: 'Ad primum argumentum dicendum quod quilibet actus caritatis meretur vitam aeternam, non quidem statim exhibendam, sed suo tempore. Similiter omnis actus caritatis meretur caritatis augmentum, non tamen statim', etc. Item, tertio dicit idem I Sent., dist. 16, art. 3, ad tertium argumentum: 'Dicendum quod columba', in qua apparuit Spiritus Sanctus, 'non fuit verum et naturale animal'. Sed in III ${ }^{a}$ parte Summae, q. 39, art. 7, dicit quod Spiritus Sanctus veram columbam formavit, in qua apparuit, etc. Et allegat ad hoc Augustinum etc. Item dicit idem I Sent. dist. 11, art. 4, quod Pater et Filius sunt duo spiratores. Sed Ia parte Summae, q. 36, art. 4, dicit quod sunt unus spirator etc. Item, dicit 36 dist. primi, art. ult., quod materia prima habet ideam aliam in Deo positam, licet imperfectam. Sed I ${ }^{\mathrm{a}}$ parte Summae, q. 15, art. 3, ad argumentum tertium dicit: 'Habet quidem materia ideam in Deo, non tamen aliam ab idea compositi. Nam materia secundum se nec habet esse nec cognosciblis est', etc. Item, dicit dist. 47 primi, art. 4, quod praecepta secundae tabulae possunt recipere dispensationem a Deo. Similiter dicit libro III, dist. 37, art. 4, quod sunt dispensabilia ex conditione aliqua. Sed I II $^{\text {ae }}$, q. 100, art. 8, dicit quod sunt indispensabilia. Item, dicit libro II Sent., dist. 28, art. 3, quod homo potest sine habitu infuso omnia lege praecepta implere quantum ad substantiam operis. Sed in $\mathrm{I}^{\mathrm{a}} \mathrm{II}^{\mathrm{ae}}$, q. 109, art. 4, dicit quod non secundum statum naturae corruptae. Item, dicit libro III, dist. 1, art. 9, quod si una persona assumpsisset duas naturas humanas, dicentur duo homines et non unus homo. Sed III ${ }^{\mathrm{a}}$ parte Summae, q. 2, art. 7, ad secundum argumentum dicit quod esset tantum unus homo. Item, libro IV, dist. 5, art. 3, salvat Magistrum Sententiarum dicendo quod potentia creandi potest communicari creaturae instrumentaliter, et dicit idem in secundo, dist. 1, q. 1, art. 3. Sed I ${ }^{a}$ parte Summe, q. 45, art. 5, dicit oppositum, et tamen dicit idem in secundo, dist. 2, art. 3, quod impossibile est creaturam creare nec principaliter nec instrumentaliter. Item, libro quarto, dist. 38 , art. 8 , ad tertium argumentum dicit quod papa in voto continentiae potest dispensare. Sed in $\mathrm{II}^{\mathrm{a}} \mathrm{II}^{\mathrm{ae}}$, q. 88, art. 11, dicit quod non, etc.”. This is also edited, from Città del Vaticano, BAV, Pal. lat. 608, in ZUMKELLER 1949, pp. 20-2.
} 
4. The Father and the Son being one or two spirators of the Holy Spirit;

5. The nature of the idea that prime matter has in God;

6. Dispensations for the last five commandments;

7. Man's being able to implement all the commandments without an infused habit;

8. One person who assumes two human natures being one or two humans;

9. Communicating creative power to a creature;

10. The pope's dispensation for a vow of continence.

In his third Principium, Conrad provides some details about his list of contradictions and the way it functions, stressing that he does not wish to insult Aquinas, whom he reveres, but merely to prove that his socius wrongly accused him of having assumed something false about Aquinas. He then explains that with each contradiction in his Concordance, the last statement is the correct one, and in each case Conrad prefers the STh over the Sentences commentary ${ }^{25}$.

The ten contradictions cover issues from all four books of the Sentences, and this might be an indication that Conrad was trying to demonstrate that Aquinas had failed consistently when dealing with different kinds of topics. Some of the contradictions (numbers 2, 4, 5, and 6) are introduced again in the third Principium, when Conrad returns to the problem of the necessity of created beings and prolongs the debate with one of his Dominican socii. Despite his professed reverence for Saint Thomas, Conrad's attitude can be characterized as more polemic this time. Aside from the list of contradictions, he now gives a few examples to show that some of Aquinas' statements can lead to heretical conclusions. For example: whatever is a necessary being is God (for Conrad); there are many creatures that are necessary beings (for Aquinas); therefore many creatures are God. Such a conclusion is heretical ${ }^{26}$. Many other

\footnotetext{
${ }^{25}$ ConRadus De Ebracho, Principium III, art. 1, ed. BRÎNZEI: "Per ista patet quod non falsum imposui Thomae, nec ut mihi videtur de possibilibus contingentibus obmisi. Reliquas concordantias nolo impugnare propter reverentiam sancti Thomae, nec illas volo impugnasse, sed me volo ostendisse quod non bene mihi imponit reverendus bachularius in dictis contradictionibus apparentibus falsum assumpsisse. Concordantia mea quam darem ego de praedictis et omnibus aliis, ubi invenirentur apparentiae contradictionum in dictis sancti Thomae, est ista, quod semper ultimo dicta sunt correctoria priorum sibi incompossibilium. Et sic standum dicerem quod intentio sua esset iudicanda secundum ultimo dicta. Non dicerem omnia esse sibi invicem compossibilia in veritate, sicut reverendus pater nititur astruere, et bene reputo mihi impossibile, sicut et ipse reputat mihi esse impossibile quod omnia dicta sua similia simul in veritate stare ostenderem, quia si hoc scivissem nunquam mihi apparuissent tot contradictiones. Si tamen sint, quod non dico, sed dico quod multae sunt ex eis et aliae praeter illas quae mihi apparent, quia forte non intelligo".

26 Ibid.: "Primo sic: quodlibet necesse esse est Deus; multae creaturae sunt necesse esse; igitur multae creaturae sunt Deus. Conclusio haeretica. Maior mea. Et minor beati Thomae". And some other examples following the same line of reasoning: "Secundo: quodlibet necesse esse est aeternum; multae creaturae sunt necesse esse; igitur multae creaturae sunt aeternae. Tertio: nullum necesse esse potest incipire aut desinere esse; sed multae creaturae sunt necesse esse; igitur multae creaturae sunt quae non possunt incipere nec desinere esse. Quarto: nullum necesse esse potest habere causam sui esse efficientem; sed multae creaturae sunt necesse esse; igitur multae creaturae sunt
} 
examples go in the same direction: Conrad attacks not only the Thomist doctrine of his socius, but also its authority.

Throughout the debate, Conrad repeats that his socius claims that Aquinas' authority has been approved by the Church in whole and in part, as stated in the papal bull that the socius cites frequently, obviously the bull Redemptionem misit announcing Aquinas' canonization on 18 July $1323^{27}$. Conrad's socius insists that the truth of his opinion relies on Aquinas' doctrine, which "is based on the bull, because the pope orders that the sayings of Thomas be held", and again concerning the Thomist doctrine Conrad gives his socius' defense: "The pope asserts it to be true and catholic" 28 . Our Cistercian then comments on this bull, examining it in order to understand how it pertains to the interpretation of Aquinas' doctrine.

Still dealing with the problem of the necessity and contingency of created being, Conrad declares more generally regarding Aquinas' teachings: "if the pope's meaning is that each and every saying of Blessed Thomas is true and must not be denied or called into doubt by any Catholic, then I willingly yield to my aforesaid reverend father and to Saint Thomas on this matter". But our Cistercian adds very ironically that "I am not yet fully informed that the pope means this, nor can one get this sufficiently from the words of the bull’"29. Conrad broadens his attack with a remark concerning the fact that even the activity of the University of Paris might then be affected by the bull and by the pope's alleged aspiration to declare the universal truth of Aquinas' doctrine. Conrad points out that, if the pope had determined that everything Aquinas said was true, then "all of the doctors who contradict Saint Thomas would be considered disobedient and would have erred and the things that they defend and their contradictory opinions would be false". Not only that, Conrad adds that, if it is disobedience to

quae non habent causam efficientem sui esse. In omnibus istis maiores sunt meae, minores beati Thomae, et conclusiones haereticae, ut dixit, igitur".

27 TORRELl 1993, vol. II, pp. 471-8; RoBiglio 2008, pp. 73-84.

${ }^{28}$ CONRADUS DE EBRACHO, Principium III, art. 1, ed. BRINZEI: "Tertia ratio principalis fundatur in bulla, quia papa mandat teneri dicta Thomae et beatus Thomas tenet illam conclusionem, igitur. Adducit multa iura et concilia quod non est contradicendum dictae conclusioni suae eo quod Thomas sanctus doctor approbatus in dictis ipsam tenuit. Confirmat, quia si fundamenta mea essent vera et conclusio quam teneo, tunc conclusio sancti Thomae ad minus in parte, ut dicit, esset falsa et haeretica, quod non est dicendum, quia papa asserit eam veram et catholicam".

${ }^{29}$ Ibid.: "Ad ista, quae videntur magis persuasiva quam probativa, dico primo quod si intentio papae est quod omnia et singula dicta beati Thomae sint vera et a nullo catholico neganda vel dubitanda, tunc in hac parte libenter cedo reverendo patri praedicto et sancto Thomae in conclusione principali, et volo omnia contradicta mea habere pro non dictis. Sed quia adhuc non sum plene informatus quod ita intendat papa, nec ex verbis bullae hoc sufficienter haberi potest, sed cum quadam generalitate dicitur, ideo de licentia reverendi patris dubitando de praedictis, ad praesens nego omnes minores praedictas. Probet ipse eas. Nec dico nec ad me pertinet dicere conclusiones esse haereticas, sed dico quod maiores credo veras semper loquendo de entitate proprie dicta, ut in qualibet addatur 'nulla entitas necessaria incepit esse', etc.". 
share doctrinal theses that are contradictory to those of Aquinas, therefore it should be considered that the University of Paris was wrong when it condemned (in 1277) the article that it is impossible for many individual angels to be of the same species, which "Blessed Thomas holds in Contra gentiles and in the Sentences" 30.

Again Conrad hastens to tell his audience that he does not have any intention to criticize Thomas or to dishonor him, but rather to honor and venerate him $^{31}$. Nevertheless, Conrad has to refute not only Aquinas' doctrine but also his very authority in order to defeat his Dominican socius in the principial debate.

Does this lack of consensus with Aquinas tell us anything about Conrad's knowledge of Aquinas' doctrine when he interpreted it as contradictory? After all, the systematic evaluation of the alleged errors that pervade the writings of the man who would become Sanctus Thomas was nothing new in Conrad's time, for it goes back at least to William de la Mare ${ }^{32}$, and the Franciscans were the champions for their permanent denunciation of the Dominican's errors. Aside from the Principia, Conrad does not quote Thomas very often in the remainder of his Sentences commentary: only 8 times in Book I, 6 times in Book II, and 5 times in Book III, although he does cite him 22 times in Book IV ${ }^{33}$. Could Conrad's access to Aquinas have been merely indirect, a not uncommon phenomenon at the time?

Let us focus on a specific treatise that circulated in the later Middle Ages, mostly in the Dominican milieu, as the Articuli in quibus frater Thomas melius in Summa quam in Scriptis ${ }^{34}$. Under this title we find different lists of from 30 to 80 contradictions (and perhaps even more after Conrad's time) that can be identified between the STh and the Sentences commentary. It seems that at its origins it was a catalogue compiled by a Dominican, the main goal being to guide and help young Friars Preacher to find solutions in case they encountered contradictions in Aquinas' writings. It should be stressed that the list was not written to denounce the contradictions, but to explain to young Dominican students why they should follow the Summa,

\footnotetext{
${ }^{30}$ Ibid.: "Secundo dico, dato quod papa taliter intendat, sicut dixi, tunc quilibet doctorum contradicentium sancto Thomae essent inoboedientes et errassent et dicta eorum et opiniones contradictoriae essent falsae. Similiter Universitas Parisiensis male condempnasset illum articulum quod in separatis a materia, puta de angelis, impossibile est esse plura individua in eadem specie, quod tamen beatus Thomas tenet Contra Gentiles et in Sententiis etc.". Cf. HISSETTE 1977, pp. 82-7.

${ }^{31}$ ConRadus De EBRAcho, Principium III, art. 1, ed. BRÎNZEI: "nec intendo inhonorare Sanctum Doctorem in dictis inquisitionibus, sed magis honorare et semper venerari". Also in ZUMKELLER 1949, p. 22, note 18.

${ }^{32}$ See ROBIN FABRE 2013 and her project of an edition of William de la Mare's Correctorium Fratris Thomae.

${ }^{33}$ BRÎNZEI-SCHABEL 2018, p. 459.

${ }^{34}$ GAUTHIER 1952, pp. 271-326, edited the Articuli, previously discussed in MANDONNET 1913, pp. 46-70. See now HOENEN 2012, pp. 210-1; ROBIN FABRE 2013.
} 
a work of maturity, rather than the Sentences commentary, written at the beginning of Thomas' theological career.

Conrad was quite familiar with the contents of the Articuli, since the contradictions that he cites in his Principia against his socii are found in the version of the Articuli containing 80 contradictions. This is also interesting from an historical point of view, since it demonstrates that this list was known among the Cistercians as well. Some of the manuscripts of this list were in Paris, more precisely in the library of the Sorbonne and probably in the College de Navarre, so in an academic context that was accessible to Conrad. Other witnesses also circulated in the Viennese academic world, where Conrad was equally very active ${ }^{35}$. The way Conrad used the Articuli reveals that they were a tool not only for a Dominican pedagogical purpose, but also for developing a rhetorical way of criticizing Aquinas, even after his canonization. The contents of the contradictions quoted by Conrad are not related to the topic of the doctrinal disagreement between him and his socii. Conrad lists these examples to spoil the sacred aura of Saint Thomas' authority. From Conrad's perspective, Aquinas might be a saint for the Church or for the pope, but among the doctors of the university, reason and logic impose rules to which Aquinas' theses sometimes fail to correspond ${ }^{36}$.

Is Conrad an individual and isolated case, the expression of a common attitude among the Cistercian theologians, or part of a more general trend of being cautious when analyzing Aquinas' doctrine? An important event in the history of the Faculty of Theology of Paris that took place almost twenty years after Conrad's first Sentences lectures might provide an answer. More precisely, let us invoke here the famous 'Monzon affair' concerning the Immaculate Conception, in the context of which issue, as noted in the beginning of this paper, the Franciscan Andreas de Novocastro had complained bitterly about Aquinas' teaching. The Monzon affair started in 1387 and ended in 1389 with the notable condemnation of the Dominican Juan Monzon's doctrine and the expulsion of the Friars Preacher from the University of Paris ${ }^{37}$.

During his vespera and resumpta ${ }^{38}$, university exercises related to the inception procedure to become master of theology, Juan Monzon, an ambitious and stubborn young Dominican, defended the thesis that the Virgin Mary contracted original sin by her

\footnotetext{
35 See the list of manuscripts in GAUTHIER 1952, pp. 279-82.

${ }^{36}$ CONRAd DE EBRACHO, Principium IV, art. 2, ed. BRÎNZEI: "Credo beatum Thomam esse sanctum, beatum et catholicum fuisse. Non tamen credo omnia dicta sua esse tam vera sicut evangelica".

${ }^{37}$ See the discussions in LAMY 2000, pp. 562-87; KRUPA 2005, pp. 633-47; and KRUPA 2013, pp. 15-25.

${ }^{38}$ Ibid., p. 16 , note 5.
} 
conception $^{39}$. But before dealing with the problem of the Immaculate Conception, Monzon upholds some of the theses that Conrad's Dominican socii defended. Equally inspired by the $S c G$ of Thomas, Monzon sustains the possibility of a creature's being simply and absolutely necessary, and according to him "it is not repugnant for a necesse esse to be caused"

The university assigned Pierre d'Ailly, at that time merely rector of the College de Navarre, to participate on the committee that examined the potential doctrinal danger of Monzon's position ${ }^{41}$. The future cardinal of Cambrai explains that one of the most serious problems in Monzon's case was that he based some of his theses on the teaching of Thomas Aquinas, which the Faculty of Theology had expressly condemned ${ }^{42}$. Among the 14 propositions condemned by the university ${ }^{43}$, articles 6 to 8 concern the issue of contingency and necessity ${ }^{44}$. Pierre d'Ailly stresses that Aquinas' authority is an insufficient basis to accept Monzon's positions, since Saint Thomas is not a perfect model, given the fact that the Thomistic doctrine is not always free from error ${ }^{45}$. The tone of d'Ailly's critique is very polemical and he

\footnotetext{
${ }^{39}$ LAMY 2000, p. 564.

${ }^{40}$ This is proposition 7. See note 44 below for the whole text.

${ }^{41}$ For Pierre d'Ailly's position in the Monzon affair, see the texts edited in Petrus De Alliaco in Du PLESSIS
} D’Argentré (1728), vol. I, pars 2, pp. 66-129: Sermo coram Papa Clemente VII Avenione habitus (pp. 66-9); Propositio facta in consistorio contra M. Ioannem de Montesono (pp. 69-74); Tractatus ex parte universitatis studii Parisiensis pro causa fidei contra quemdam fratrem Johannem de Montesono Ordinis Praed. editus a Petro de Alliaco Episcopo et Cardinali Cameracensi circa annum 1388 (pp. 75-129). These texts were also edited by Du Pin in JOANNES Gersonius 1706, coll. 697-722.

${ }^{42}$ Petrus de Alliaco, Tractatus ex parte universitatis, p. 82: "Sed huic articulo opponuntur tria, quae ponit dictus Frater in supplicatione sua, seu querela Domino Papae exposita, in qua fere tot sunt mendacia, quot verba. Primum est, quia aliquae conclusionum suarum trahuntur ex doctrina S. Thomae, quam Facultas Theologiae alias expresse commendavit, et Dominus Stephanus Episcopus Parisiensis per suas litteras approbavit'. Pierre d'Ailly's attitude toward Thomas' authority has sparked some interesting papers: MÜLLER 2005; TABER 1990; KELLY 1976; GLORIEUX 1966; OUY 1963.

${ }^{43}$ The list has been edited in Schedula facultatis theologiae parisiensis, in DENIFLE-CHATELAIN 1894, nr. 1559, pp. 491-6.

${ }^{44}$ Ibid., p. 494: "Sexta proposicio: Ponere aliquod creatum vel aliqua creata esse simpliciter et absolute neccesse esse, non est in aliquo contra fidem. Revocanda est tanquam falsa et male sonans in fide secundum modum loquendi communem theologorum, nec est ex dictis S. Thome asserenda in sensu quem reddit, attenta prima proposicione, quam assumit ad declaracionem dicte proposicionis, in qua dicit quod aliqua res creata est simpliciter et absolute neccesse esse, equippollet isti: aliqua res creata impossibile est non esse. Septima proposicio: Neccesse esse non repugnant esse causatum. Revocanda est tanquam falsa et erronea in fide, attento primo correlario ejusdem proposicionis cum sua probacione, in qua dicit quod necesse esse est illud, quod est immutabile tam secundum substanciam, quam secundum accidens, quod soli Deo congruit. Octava proposicio: Magis est consonum fidei ponere aliquid citra primum esse absolute et simpliciter neccesse esse, quam ponere ipsum sine aliqua addicione esse neccesse esse. Revocanda est tanquam falsa et erronea propter falsam implicacionem et erroneam comparacionis, que includit, quod aliquam rem creatam esse neccesse esse, est consonum sacre scripture, et per consequens aliquod creatum esset increatum, quod contradiccionem includit".

${ }^{4}$ Petrus de Alliaco, Tractatus ex parte universitatis, p. 82: "Ad secundum respondetur, quod ex praedicta bulla Domini Urbani, vel ex praeallegata littera Domini Stephani, aut alia quacumque littera authentica, non potest sufficienter concludi, quod S. Thomae doctrina sit in omnibus approbata, sicut clare ostenditur in 3 cap. huius tractatus. Et ad hoc adjiciunt aliqui talem rationem, quia illa doctrina non potest sic esse in omnibus approbata, quae multa continet in fide erronea. Sed, ut docent, praedicta sancti Thomae doctrina non solum in materia de 
remains in the same frame of mind as that of Conrad during his disagreement with his Dominican socii. More than that, d'Ailly follows the same hermeneutical approach and proves the inconsistency of Thomas' thinking by listing some of the contradictions that we already found under Conrad's pen. The Articuli mentioned above as a source of Conrad seem to be the same tool that d'Ailly used in building his defense against Monzon ${ }^{46}$. Pierre d'Ailly has even been characterized as "the initiator of a new censure" for this, since during Monzon's process he "emphasized the role of the contemporary theologian, the scholastic, and even mentioned the University of Paris by name" 47 . Of course, Conrad of Ebrach was already employing the same tools during his dispute with his Dominican socii, naming the University of Paris explicitly (Universitas Parisiensis male condempnasset istum articulum ${ }^{48}$ ) and drawing attention to the danger of a scholastic authority's importing error into one's defense of a doctrinal position.

Conrad of Ebrach (who represents here an individual reaction) and Pierre d'Ailly (who represents here an institutional reaction) are two important examples of interpreters of Thomas Aquinas outside of the main camps in the dispute between the Franciscans and the Dominicans. In both cases, the authority of Aquinas was invoked for the same philosophical position on the necessity or contingency of created being defended by the various Dominican students (Conrad's socii or Juan Monzon), inspired by the $S c G$, and this position and invocation aroused the same reaction in the opposing camps. For an adversary, quoting contradictions between the Sentences and the STh that had been catalogued by Dominicans themselves appeared to be a perfect hermeneutical weapon, a tool that highlighted the lack of consistency of Aquinas' doctrine. The opponents did not attack the theologian's authority qua saint ${ }^{49}$, but only the saint's authority qua theologian.

\section{Interpreting the $S T h$ on Divine Foreknowledge}

\footnotetext{
absoluta necessitate creaturae (de qua, occasione praesentis controversiae, inferius in tribus ultimis conclusionibus tertii capituli specialiter tractabitur), sed etiam in pluribus aliis multa continet in fide erronea. Quod declarat".

${ }^{46}$ According to GlORIEUX 1966, p. 50: “certains traits, que comporte le texte de Pierre d'Ailly, laisseraient entendre qu'il avait eu sous les yeux, sans doute dans la Bibliothèques du Collège de Navarre, un texte assez proche de celui du Paris, Nat. lat. 14551, ou Univers. 213 ou Troyes 625”.

${ }^{47}$ KELLY 1976, p. 148.

${ }^{48}$ See above, note 29.

49 The Sermo de Sancto Thoma d'Aquino (ms. Krakow, Biblioteka Jagiellońska 1197, ff. 101ra-106rb), which Conrad wrote in 1386 in praise of Aquinas' memory, while he was teaching theology at the University of Vienna, gives us the proof that, even if he criticized the inconsistency of Aquinas' doctrine, Conrad did not oppose his canonization. This Sermo also confirms the University of Vienna's desire to avoid a similar situation to the Monzon affair in Paris. Cf. LAMY 2000, pp. 587-91.
} 
By the end of the Middle Ages and the beginning of the commentary tradition on the STh, one context where there appeared to be a contradiction between the Sentences commentary and the Summa was divine foreknowledge ${ }^{50}$. Thomas Aquinas was such a significant and controversial author that, regardless of how innovative or derivative his solution to a given problem was, that response often became the starting point for the future debate. Nevertheless, the issue of divine foreknowledge of future contingents was exceptionally controversial. Of the 118 articles that William de la Mare criticized in his Correctorium fratris Thomae, written in 1277-79, the one against the STh I, q. 14, art. 13, on divine foreknowledge, is number three, and here and in the four Dominican Correctoria of William's critique composed before 1284 this topic appears to be in the top ten in terms of the length of the treatment ${ }^{51}$. More impressive, in the first complete commentary on the Summa, that of Cajetan, published in the early 1500s on the eve of the Reformation and reprinted along with the Summa itself in the Leonine edition, Cajetan's commentary accompanying the article on divine foreknowledge occupies 12 columns of dense text, the longest of all the articles of STh $\mathrm{I}^{52}$. Indeed, of the well over 2000 articles in the entire $S T h$, only three receive more attention from Cajetan, and very few have even half as many pages of commentary ${ }^{53}$. In what follows, we will not be concerned with the doctrinal issue per se, nor with the correct reading of Aquinas, but merely with the fact that interpreting the Summa was already a focus of debate soon after it was written.

\subsection{Presence to Eternity}

\footnotetext{
${ }^{50}$ For the reception of Aquinas on this issue, see, for example, GROBLICKI 1938; DECKER 1967, pp. 172-89; HOENEN 1993, pp. 166-72; ALLINEY 1999; and the introductions to some of the editions cited below. For the dating of the various texts, see the same introductions and chapters in EVANS 2002, ROSEMANN 2010, and SCHABEL 2007. ${ }^{51}$ KNAPwEll, Correctorium corruptorii 'Quare', ed. GloriEuX (1927), William de la Mare's text on pp. 17-21 and Knapwell's response on pp. 21-5; ORFORD, Correctorium corruptorii 'Sciendum', ed. GLORIEUX (1956), pp. 38-44; MACClESFIEld (?), Correctorium corruptorii 'Quaestione', ed. Muller (1954), William de la Mare's text on pp. 17-19 and Macclesfield's (?) response on pp. 19-23; QUIDORT PARISIENSIS, Correctorium corruptorii 'Circa', ed. MulLer (1941), pp. 22-32.

${ }^{52}$ Caietanus 1888 , In I, q. 14, art. 13, pp. 187a-193b.

53 The longest is CAIETANUS 1895, In II-II, q. 24, art. 7, pp. 183a-190b (Utrum caritas augeatur in infinitum), at 14.5 columns, followed by CAIETANUs 1903, In III, q. 4, art. 2, pp. 74a-81b (Utrum Filius Dei assumpserit personam), and q. 17, art. 2, pp. 223a-229b (Utrum in Christo sit tantum unum esse), each 13 columns long. The text for CAIETANUS 1906, In III, q. 80, art. 12, pp. 244a-255b (Utrum liceat sumere corpus Domini sine sanguine), is actually longer at 21 columns, but it includes separate questions by Cajetan inspired by the later Hussite controversy. Finally, CAIETANUS 1897, In II-II, q. 122, art. 4, pp. 479a-485b, on the suitability of the Ten Commandments, is equally long as the article on foreknowledge.
} 
The problem of divine foreknowledge of future contingents was two-fold: how does God know what has not yet happened and how is it that this knowledge safeguards the contingency of futures that do not occur of necessity? The main and most controversial element of Aquinas' solution derived from Augustine and Boethius and relied on God's atemporal eternity. Let us quote his responsio in the $S T h$ in full:

\begin{abstract}
Something contingent can be considered in two ways. In one way [something contingent can be considered] in itself, according to which it already exists in actuality. In this way it is not considered as future, but as present, and not as contingent to both sides (ad utrumlibet), but as determined to one side. Because of this, it can be subject to sure cognition infallibly, as to the sense of vision, just as when I see Socrates sitting. In the other way a contingent can be considered as it is in its cause. In this way it is considered as future and as contingent, not yet determined to one side, because a contingent cause relates (se habet) to opposites. In this way the contingent is not subject to any cognition with certitude. Thus whoever knows a contingent effect merely in its cause has nothing but conjectural knowledge of it. But God knows all contingents, not only as they are in their causes, but also as each of them exists in actuality in itself. And although in actuality contingents come about successively, God does not know contingents successively as they are in their being in the way we do, but all at once, because His knowledge is measured by eternity, just as His being, while eternity exists all at once and encompasses all of time $[\ldots]$. Thus all things that exist in time are present to God from eternity, not only by that ratio by which He has the rationes of things present within Him, as some say, but because His gaze is carried (intuitus fertur) from eternity over all things as they are in their presentness. Thus it is manifest that contingents are known by God infallibly insofar as they are subject to the divine vision (conspectus) according to their presentness, and yet they are future contingents compared to their causes ${ }^{54}$.
\end{abstract}

\footnotetext{
${ }^{54}$ STh I, q. 14, art. 13, resp., vol. IV, p. 186a-b: "Ad cuius evidentiam, considerandum est quod contingens aliquod dupliciter potest considerari. Uno modo, in seipso, secundum quod iam actu est. Et sic non consideratur ut futurum, sed ut praesens: neque ut ad utrumlibet contingens, sed ut determinatum ad unum. Et propter hoc, sic infallibiliter subdi potest certae cognitioni, utpote sensui visus, sicut cum video Socratem sedere. Alio modo potest considerari contingens, ut est in sua causa. Et sic consideratur ut futurum, et ut contingens nondum determinatum ad unum: quia causa contingens se habet ad opposita. Et sic contingens non subditur per certitudinem alicui cognitioni. Unde quicumque cognoscit effectum contingentem in causa sua tantum, non habet de eo nisi coniecturalem cognitionem. Deus autem cognoscit omnia contingentia, non solum prout sunt in suis causis, sed etiam prout unumquodque eorum est actu in seipso. Et licet contingentia fiant in actu successive, non tamen Deus successive cognoscit contingentia, prout sunt in suo esse, sicut nos, sed simul. Quia sua cognitio mensuratur aeternitate, sicut etiam suum esse: aeternitas autem, tota simul existens, ambit totum tempus, ut supra dictum est. Unde omnia quae sunt in tempore, sunt Deo ab aeterno praesentia, non solum ea ratione qua habet rationes rerum apud se praesentes, ut quidam dicunt: sed quia eius intuitus fertur ab aeterno super omnia, prout sunt in sua praesentialitate. Unde manifestum est quod contingentia et infallibiliter a Deo cognoscuntur, inquantum subduntur divino conspectui secundum suam praesentialitatem: et tamen sunt futura contingentia, suis causis comparata".
} 
Despite the fact that Aquinas was following both Augustine and Boethius, he cited neither, and perhaps for this reason most later commentators did not really discuss Aquinas' debt, either to defend or to attack him. Aquinas dealt with the problem of divine foreknowledge of future contingents in several places in similar ways, most notably in his Sentences commentary, in the $S c G$, in the disputed questions De veritate, and in the $S T h^{55}$. There is a great deal of overlap in these discussions, and the importance of Aquinas' Sentences commentary in particular means that it is not always easy to identify when his later supporters and opponents were dealing with the $S T h$ rather than some other writing. Certain phrases, such as intuitus fertur ab aeterno super omnia, are unique to the $S T h$, however, and this allows us to see that, over time, this treatment became the most important.

As is well known, from the start, theologians disagreed about what Aquinas meant when he wrote that "all things that exist in time are present to God from eternity [...] because His gaze is carried from eternity over all things as they are in their presentness": did things somehow exist in themselves eternally according to their actual being, or rather in some other way? The Dominicans themselves disagreed about Aquinas' intent and even about whether Aquinas was correct. Durand of Saint-Pourçain (ca. 1310), for example, wrote that two interpretations circulated for God's knowing future contingents according to their actual existence: one, "as they actually exist already"; two, according to "the proper and distinct actual existence that they will have in the process of time in themselves". On the first interpretation, "All future contingents are eternally present to God according to their actual existence, and so, according to this [existence] they are eternally known by God"56. In the first version of his Sentences commentary, Durand remarked:

\footnotetext{
${ }^{55}$ Specifically Thomas Aquinas, Scriptum in primum librum Sententiarum, dist. 38, q. 1, art. 5; ScG I, cap. 6667; Quaestiones disputatae de veritate, q. 2, art. 12; and STh I, q. 14, art. 3.

${ }^{56}$ Durandus de Sancto Porciano, In primum librum Sententiarum, dist. 38, q. 3, art. 2, ed. SChabelFRIEDMAN-BALCOYIANNOPOULOU (2001), pp. 254-5, 11. 124-71: "Sciendum quod istud potest habere duplicem intellectum: unum, utrum Deus cognoscat futura contingentia quantum ad suam actualem existentiam, id est ea actu existere... Alius potest esse intellectus, scilicet quod Deus cognoscat futura contingentia quantum ad eorum actualem existentiam, non quod Deus cognoscat ea iam existere, sed quia Deus novit ab aeterno illam propriam et distinctam existentiam actualem quam habebunt processu temporis [...]. Et hoc $<$ primo $>$ modo dicunt quidam quod [...] omnia autem futura contingentia sunt ab aeterno praesentia Deo secundam suam actualem existentiam, et ideo, secundum eam, sunt ab aeterno a Deo cognita".
} 
Some claim that this is Friar Thomas' intention in the Scriptum and in the Summa, part I, question 14 , article 13, because of some words he says there. But I don't think this is true. And first I show that this statement is not true in itself, second that this was not his meaning ${ }^{57}$.

Durand goes on to quote explicitly and at length Aquinas' Sentences commentary and the Summa to refute this view, using, he says, the very words that others had employed for the opposite position. Durand's younger confrere James of Lausanne (ca. 1315) followed Durand in this, remarking that "this appears to be Thomas" intent, as is clear through his words" his later redactions Durand eliminated the explicit references to and quotations of Aquinas, and another confrere, Peter of Palude (ca. 1312), cautiously approved his interpretation with some qualifications $^{59}$. In the 1320s, however, after Aquinas had become Saint Thomas, the Dominican Bernard Lombardi (ca. 1328) copied Durand's later redaction only to add a critique beginning with the formula, "But this refutation does not get at the Holy Doctor's understanding". After explaining Aquinas' position at length, Bernard interjects, "But there is a doubt about this, because the Holy Doctor, in part I, question 14, article 13, states that 'all things that exist in time are present to God from eternity",, and so on, which quotation Bernard then strives to interpret ${ }^{60}$.

For the most part, while the Dominicans could not agree on the correct interpretation of Aquinas on this issue, they did defend as doctrinally true their own interpretations, or at least what they claimed to be their interpretations. The main exception was James of Metz (ca. 1302), who not only rejected as doctrinally flawed Aquinas' opinion according to his own interpretation, but even went out of his way to refute other interpretations:

Some explain the dictum of this opinion in this way: God knows future contingents with the certitude of presentness not because they are present to Him, because this does not seem intelligible, but

\footnotetext{
57 Durandus de SAncto Porciano, In primum librum Sententiarum, redactio A, dist. 38, q. 3, art. 2, ed. SCHABEL-FriedMAN-BALCOYiAnNOPOUlOU (2001), p. 274, 11. 1-4: "Hoc autem dicunt quidam esse de intentione fratris Thomae, hic in Scripto et in Summa, prima parte, quaestione 14, articulo 13, propter quaedam verba quae ibi dicit. Quod non puto verum esse. Et primo ostendo quod dictum non est in se verum, secundo quod non fuit de mente eius".

${ }^{58}$ IACOBUS LAUSANENSIS, In primum librum Sententiarum, redactio B, dist. 38, q. 2, ed. SCHABEL-FRIEDMANBALCOYIANNOPOUlOU (2001), p. 281, 1. 161: "Et ista videtur esse intentio Thomae, ut patet per eius verba".

59 Petrus De Palude, In primum librum Sententiarum, dist. 38, q. 3, art. 2, ed. SchABEL-FriEDMANBALCOYIANNOPOULOU (2001), p. 266, 11. 491-504.

60 Bernardus LOMBARDI, In primum librum Sententiarum, dist. 38, art. 2, ed. SCHABEL-FRIEDMANBALCOYIANNOPOUlOU (2001), p. 297, 11. 24-5: "Ista autem reprobatio non vadit ad mentem Sancti Doctoris"; p. 298, 11. 65-7: "Sed circa ista est unum dubium, quia Sanctus Doctor, prima parte, quaestione 14, articulo 13, dicit quod 'omnia quae sunt in tempore sunt Deo ab aeterno praesentia [...]"'.
} 
because He knows them with cognition as certain as if they were present to Him, or in the way I know them when they are present to me. But is this the intention of the one giving the opinion? It does not seem that this was his intention, as one has it in book I of Summa contra gentiles, chapter $66^{61}$.

In his rebuttal a few years later, a follower of Hervaeus Natalis rejected James of Metz' interpretation and defended the doctrine of his own reading of Aquinas ${ }^{62}$.

For the Dominicans, the very interpretation of the position of the teaching doctor of the order thus played an important role in discussions both before and after Aquinas' canonization. Yet this was also true of some non-Dominicans. For instance, in all three redactions of his question on foreknowledge in his Quaestiones ordinariae on divine knowledge, the secular master John of Pouilly (1306) combined his position with an interpretation of Aquinas, although anonymously. We quote the first redaction:

\begin{abstract}
Those who posit that God knows a future contingent... according to how it is in itself actually do not seem to understand by what they say in their positio that future things known by God are actually in reality under actual presence as they will be later in time, but that they are known with equal certainty and by the same knowledge even according to that being, just as when they have it in themselves ${ }^{63}$.
\end{abstract}

In his Quodlibeta, another secular master, Peter of Auvergne (1301), also linked his solution to the proper interpretation of Aquinas, concluding, "And I believe that this was the intention of that doctor who posited that future contingents coexist with God"64. Likewise, in both the first and sixth Quodlibeta of Guy Terrena (1313 and ca. 1320), the Carmelite defended Aquinas

\footnotetext{
${ }^{61}$ Iacobus Metensis, In primum librum Sententiarum, dist. 38, tertium principale, art. 2, ed. SCHABEL (2014), p. 65, 11. 136-40: "Et ideo exponunt quidam dictum opinionis sic: quod Deus cognoscit futura contingentia certitudine praesentialitatis non quia sint sibi praesentia, quia hoc non videtur intelligibile, ut habitum est, sed quia ea ita certa cognitione cognoscit acsi essent sibi praesentia, vel sicut ea cognosco quando sunt mihi praesentia, et illa expositio est vera. Si tamen sit intentio opinantis? Sed non videtur quod haec fuerit eius intentio, sicut habetur in Summa contra gentiles, libro primo, capitulo 66". Cf. James' Additiones, p. 64, 11. 104-10: "Et ideo qui tenent opinionem contrariam glosant quod voluit Thomas dicere quod cognitioni divinae contingentia futura fuerunt praesentia $a b$ aeterno, non praesentialitate rei ut res fuerit coram eo ab aeterno, sed praesentialitate cogniti, quia ab aeterno cognovit sicut ego quando praesens est mihi. Sed utrum fuerit haec intentio sua, non videntur sonare verba sua". ${ }^{62}$ Hervaeus Natalis (Pseudo?), Correctorium Iacobi Metensis, I Sententiarum, dist. 38, ed. Schabel (2014).

${ }^{63}$ Iohannes DE Polliaco, Quaestiones ordinariae, q. 1, redactio 1, ed. SCHABEL (2011), p. 174, 11. 269-74: "Ponentes ergo quod Deus cognoscit futurum contingens non solum ut est in suis causis, sed secundum quod est actu in se ipso, non videntur intelligere per ea quae dicunt in sua positione quod res futurae cognitae a Deo sint actu in rerum natura sub praesentia actuali sicut erunt postea in tempore, sed quod aeque certitudinaliter et eadem cognitione cognoscuntur etiam secundum illud esse sicut cum habent illud esse in se ipsis". Cf. redactio 2, pp. 204-5, 11. 621-35, and redactio 3, pp. 216-7, 11. 354-94.

${ }^{64}$ Petrus de Alvernia, Quodlibet IV, q. 2, art. 4, ed. Schabel (2015), p. 379, 11. 114-6: "Et hanc credo fuisse intentionem illius doctoris qui posuit futura contingentia coexistere Deo".
} 
against his detractors by asserting, in the first case, that "these people, in my judgment, do not get at the understanding of the doctor who posits this position", which Guy then interprets ${ }^{65}$.

In contrast, the Franciscans, beginning with William de la Mare, attacked Aquinas' theory, regardless of whether Aquinas meant that things actually existed from eternity. Some, like John Duns Scotus (ca. 1302), assumed that Aquinas referred to their actual existence ${ }^{66}$, but many Franciscans included in their refutation possible interpretations. Indeed, according to his rubrics, Peter Auriol (1316) explicitly refutes both “Thomas' opinion in part I, question 14, article 13, in Book I of the Scriptum, and in Book I of Contra gentiles", as well as "Durand's interpretation"67. Landolfo Caracciolo (ca. 1318) provides another example: "When it is said that all things are present to God, either you understand it in real being, and this is impossible from eternity, or only in intelligible being". In the latter case, since it cannot be distinct from the knower, Landolfo concludes, "then it begs the question: God knows all things infallibly because He has all things in His knowledge" ${ }^{\circ 8}$.

In his own Summa theologiae, the Carmelite Gerard of Bologna (ca. 1315) traced this ongoing Dominican-Franciscan debate over the interpretation of Aquinas, after quoting verbatim the position as presented in Aquinas' STh. First, Scotus' critique is offered, then what would have been Aquinas' response, then Durand's interpretation and defense of the Summa passage is given, followed by the typical Franciscan refutation, deriving from William de la Mare. Again the interpretations of the likes of the Dominicans Durand and James of Metz are presented as a rebuttal, before Gerard concludes his opinio propria with a lengthy interpretation of the phrase "a future contingent is understood as it is in itself actually existing", leaning toward a Durandist position ${ }^{69}$.

\subsection{Proximate and Remote Causes}

\footnotetext{
${ }^{65}$ Guido Terreni, Quodlibet I, q. 2, art. 2, ed. Schabel (2003), p. 189, 11. 58-62: "Sed isti, meo iudicio, non vadunt ad mentem doctoris ponentis positionem, quia ipse non vult $<$ quod $>$ futurum sic coexistat aeternitati ut realiter sit extra Deum et Dei entitatem, quia ipse ponit quod res non sunt, immo sunt nihil, ante earum creationem, sed ponit hanc futuri praesentialitatem quantum ad esse cognitum in Deo".

${ }^{66}$ E.g., Duns Scotus, Ordinatio in primum librum Sententiarum, dist. 38 pars 2 et dist. 39 qq. 1-5, ed. BALIĆ et al. (1963), pp. 407, 1. 19-411, 1. 14.

${ }^{67}$ Petrus Aureoli, Scriptum in primum librum Sententiarum, dist. 38, art. 1, ed. SCHABeL (1995), pp. 93, 11. 1424, and 103-6, 11. 351-401.

${ }^{68}$ CARACCIOLI, In primum librum Sententiarum, dist. 39, art. 2, ed. SCHABEL (1999), pp. 324-5: “Cum dicitur quod omnia sunt in Deo presentia, aut intelligis in esse reali, et hoc est impossibile ab eterno, aut in esse solum intelligibili. Et quero si istud esse est aliquod esse positivum distinctum a cognoscente et cognitione? Et certum est quod non, quia etiam esset reale. Si autem non est distinctum ab ipsa notitia, tunc petitur principium: Deus novit omnia infallibiliter quia habet omnia in notitia sua".

${ }^{69}$ Gerardus BonONIENSIS, Summa theologiae, q. 25, art. 7, ed. SCHABEL (2003), pp. 171-80, 11. 29-295.
} 
The issue of presence to eternity was certainly not the only aspect of Thomas Aquinas' theory of divine foreknowledge that provoked criticism and required interpretation. Aquinas answered the question of how God knows the future in itself via the eternity device. As quoted above, in the STh's responsio the alternative was described as follows: a contingent in its cause "is considered as future and as contingent, not yet determined to one side [...]. In this way the contingent is not subject to any cognition with certitude. Thus whoever knows a contingent effect merely in its cause has nothing but conjectural knowledge of it"70. Most readers understood this as Aquinas' position, regardless of whether they agreed with it. Nevertheless, Aquinas himself appears to have spoken differently in his $S c G$, although his last words are rather vague:

\begin{abstract}
Just as from a necessary cause the effect follows with certainty, so it does from a complete contingent cause, if it is not impeded. But since God knows everything, He knows not only the causes of contingents, but also those things by which they can be impeded. Therefore He knows through certitude an contingentia sint vel non sint ${ }^{71}$.
\end{abstract}

On this issue, without mentioning Aquinas by name, Durand offered Aquinas' position from the STh, saying "quidam dicunt", then rejected this, and, following James of Metz, endorsed a theory that paraphrases what Aquinas states in the $S c G$, that in knowing all the causes and impediments, God knows the future with certainty ${ }^{72}$. Durand's presentation met with partial approval from Peter of Palude, while James of Lausanne claimed to reconcile the "antiqua opinio" with Durand's, in reality adopting Durand's stance, again without citing Aquinas ${ }^{73}$.

\footnotetext{
${ }^{70}$ STh I, q. 14, art. 13, resp., p. 186a: "Et sic consideratur ut futurum, et ut contingens nondum determinatum ad unum... Et sic contingens non subditur per certitudinem alicui cognitioni. Unde quicumque cognoscit effectum contingentem in causa sua tantum, non habet de eo nisi coniecturalem cognitionem".

${ }^{71}$ ScG I, cap. 67, vol. XIII, p. 190b, 11. 1-7: "Sicut ex causa necessaria certitudinaliter sequitur effectus, ita ex causa contingenti completa si non impediatur. Sed, cum Deus cognoscat omnia, ut ex supra dictis patet, scit non solum causas contingentium, sed etiam ea quibus possunt impediri. Scit igitur per certitudinem an contingentia sint vel non sint”.

${ }^{72}$ Durandus de Sancto Porciano, In primum librum Sententiarum, dist. 38, q. 3, art. 2, ed. SchabelFRIEDMAN-BALCOYIANNOPOULOU (2001), p. 253, 11. 97-106: "Sed istud non videtur verum, quia sicut ex causa necessaria sequitur effectus necessarius, sic ex causa impedibili, si non sit impedita, sequitur effectus contingens infallibiliter... sic cognita causa impedibili et omnibus quae eam impedire possunt et insuper eis quae eam impedient vel non impedient, certitudinaliter potest cognosci quis effectus eveniet vel non eveniet".

73 Petrus de Palude, In primum librum Sententiarum, dist. 38, q. 3, art. 2, ed. Schabel-FriedmanBALCOYIANNOPOULOU (2001), pp. 264-6, 11. 445-81; IACOBUS LAUSANENSIS, In primum librum Sententiarum, redactio B, dist. 38, q. 1, art. 2, ed. SCHABEL-FriedMAN-BALCOYIANNOPOULOU (2001), pp. 278-80, 11. 36-119.
} 
Bernard Lombardi, on the other hand, interpreted Durand's discussion as a direct refutation of Aquinas' theory in the STh, forcing Bernard to deal with the situation. Now, the first argumentum principale that Aquinas gave in the STh against God's foreknowing future contingents declares that, since a necessary cause produces a necessary effect, and God's knowledge is the cause of things that are known, then just as God's knowledge is necessary, so are the things known, not contingent ${ }^{74}$. Aquinas' brief response in the $S T h$, paralleled in other works, is as follows:

\begin{abstract}
Although the supreme cause is necessary, the effect can be contingent because of a contingent proximate cause, just as the germination of a plant is contingent because of a contingent proximate cause, although the sun's motion, which is the first cause, is necessary. Similarly, the things known by God are contingent because of proximate causes, although God's knowledge, which is the first cause, is necessary ${ }^{75}$.
\end{abstract}

Bernard, therefore, was able to interpret Aquinas' responsio as referring merely to the proximate causes: "Regarding Durand's arguments against the Holy Doctor it is clear that they are not valid, because [Durand] considers causes one of which is necessary and determined, as God, while the Doctor considers only the contingent cause". Nevertheless, in reaching this conclusion Bernard had said that contingent causes ultimately go back to a determinate one, otherwise one would have an infinite regress ${ }^{76}$.

In our view, Bernard's interpretation of Aquinas' responsio is an attempt to preserve Aquinas' reputation in an era when both science and the issue of divine foreknowledge had moved on. On the one hand, even some Dominican Thomists held that knowing the entire causal chain, presumably in natural causation, would result in certain knowledge of the future, while,

\footnotetext{
${ }^{74}$ STh I, q. 14, art. 13, arg. 1, vol. IV, p. 186a: "Videtur quod scientia Dei non sit futurorum contingentium. A causa enim necessaria procedit effectus necessarius. Sed scientia Dei est causa scitorum, ut supra dictum est. Cum ergo ipsa sit necessaria, sequitur scita eius esse necessaria. Non ergo scientia Dei est contingentium".

${ }^{75} \mathrm{Ibid}$., ad 1, p. 186b: "Ad primum ergo dicendum quod, licet causa suprema sit necessaria, tamen effectus potest esse contingens, propter causam proximam contingentem: sicut germinatio plantae est contingens propter causam proximam contingentem, licet motus solis, qui est causa prima, sit necessarius. Et similiter scita a Deo sunt contingentia propter causas proximas, licet scientia Dei, quae est causa prima, sit necessaria".

${ }^{76}$ Bernardus Lombardi, In primum librum Sententiarum, dist. 38, art. 1, ed. SCHABEL-FriedmanBALCOYIANNOPOUlOU (2001), p. 296, 11. 6-20: "Sciendum tamen quod sicut causae per accidens reducuntur ad per se, sic omne contingens ad aliquam causam determinatam [...]. Et per hoc patet, ad rationes Durandi contra Sanctum Doctorem, quod non valent, quia accipit causas quarum altera est necessaria et determinata, ut Deus, Doctor autem accipit praecise causam contingentem".
} 
on the other, human free will had become the focus of attention ${ }^{77}$. Citing Aristotle, Bernard helped Aquinas save face by the mere declaration that "the effect follows the proximate cause". Then Bernard added that, "because God acts via free choice, which is a contingent principle, therefore the effects are contingent" ${ }^{78}$. This was perhaps a nod to Franciscan criticisms of Aquinas. Scotus, for example, famously held that the chain of natural causation is necessary, once set in motion, so contingency has to be grounded in the first cause, the divine will ${ }^{79}$. Curiously, like Bernard, the Franciscan Peter Auriol also explicitly interpreted Aquinas in the STh and Sentences commentary in opposition to the Scotist charge that Aquinas held that God is a necessary cause ad extra, although Auriol still disagreed with Aquinas' solution based on proximate causes ${ }^{80}$. Once natural causation had been accepted as necessary, supposing God's general influence, by Bernard's time the main question had become how God knows future contingents that stem from human free will, outside natural causation, something that neither Aquinas nor Scotus had dealt with in this context. Whether disingenuously or not, Bernard felt the need to interpret Aquinas in a way that brought the Holy Doctor up to date with current thinking.

\subsection{As It Is in the Soul}

Even if human free will was not an explicit issue for Aquinas in this context, Aquinas still had to explain how what God foreknows can remain contingent, the other dilemma of the foreknowledge problem. Indeed, the third opening argument in the STh merely asserts that what is known, even by us, must necessarily be, and so much more so if God knows it ${ }^{81}$. The second argument is propositional: if the antecedent of a conditional is absolutely necessary, so is the

\footnotetext{
${ }^{77}$ Durand brought up human free will in his argument In contrarium: DURANDUS DE SANCTO PORCIANO, In primum librum Sententiarum, dist. 38, q. 3, art. 2, ed. SCHABEL-FriedMAN-BALCOYIANNOPOUlOU (2001), p. 251, 11. 35-41.

78 Bernardus Lombardi, In primum librum Sententiarum, dist. 38, art. 1, ed. SCHABel-FriedmanBALCOYIANNOPOULOU (2001), p. 296, 11. 12-17: "Sed hic est unum dubium, quia si contingens habet causam determinatam semper, contingentia perit a rebus. Ad hoc dicendum quod non, quia secundum Philosophum, secundo Physicorum, effectus sequitur causam proximam, et quia Deus agit mediante libero arbitrio, quod est principium contingens, ideo effectus sunt contingentes".

${ }^{79}$ Duns Scotus, Ordinatio in primum librum Sententiarum, dist. 38 pars 2 et dist. 39 qq. 1-5, ed. Balić et al. (1963), pp. 412, 1. 11-413, 1. 16.

${ }^{80}$ Petrus Aureoli, Scriptum in primum librum Sententiarum, dist. 39, art. 2, ed. SCHABEL (1995), pp. 174-5, 11. 549-56.

${ }^{81}$ STh I, q. 14, art. 13, arg. 3, vol. IV, p. 186a: "Praeterea, omne scitum a Deo necesse est esse: quia etiam omne scitum a nobis necesse est esse, cum tamen scientia Dei certior sit quam scientia nostra. Sed nullum contingens futurum necesse est esse. Ergo nullum contingens futurum est scitum a Deo".
} 
consequent. "But this is a true conditional: 'If God has foreknown that this is future, this will be', because God's knowledge is only of true things. But the antecedent of this conditional is absolutely necessary, both because it is eternal and because it is signified as something past. Therefore the consequent is also necessary absolutely", which destroys contingency ${ }^{82}$.

While rejecting other solutions, including that of Bonaventure, and ascribing to distinctions that were common to almost all scholastics, Aquinas responded by accepting that the antecedent is absolutely necessary, but went on as follows:

\begin{abstract}
When something that pertains to an act of the soul is posited in the antecedent, the consequent is to be taken not as it is in itself, but as it is in the soul, for the being of a thing in itself is one thing, the being of a thing in the soul is another. For example, if I say, 'If the soul understands something, that is immaterial', one must understand that that is immaterial as it is in the intellect, not as it is in itself. Similarly, if I say, 'If God has known something, that will be', one must understand the consequent as it is subjected to divine knowledge, namely as it is in its presentness, and in this way it is necessary just as the antecedent ${ }^{83}$.
\end{abstract}

Although much of this parallels what Aquinas wrote in De veritate, the reference to the "act of the soul" is unique to the STh in this context, and some later commentators called this a regula. Dominicans do not seem to have paid much attention to this rule at first, but the secular theologians Henry of Harclay (ca. 1305) and Thomas Wylton (ca. 1315), the Carmelites Gerard of Bologna and John Baconthorpe (early 1320s), the Franciscans Alexander of Alessandria (ca. 1307) and Peter Auriol, and the Augustinian Gregory of Rimini (ca. 1343) argued against it ${ }^{84}$,

\footnotetext{
${ }^{82}$ Ibid., arg. 2, p. 186a: "Praeterea, omnis conditionalis cuius antecedens est necessarium absolute, consequens est necessarium absolute [...]. Sed haec est quaedam conditionalis vera, si Deus scivit hoc futurum esse, hoc erit: quia scientia Dei non est nisi verorum. Huius autem conditionalis antecedens est necessarium absolute: tum quia est aeternum; tum quia significatur ut praeteritum. Ergo et consequens est necessarium absolute. Igitur quidquid scitur a Deo, est necessarium. Et sic scientia Dei non est contingentium".

${ }^{83}$ Ibid., ad 2, p. 187a: "Unde dicendum est quod hoc antecedens est necessarium absolute [...]. Et ideo aliter dicendum est, quod quando in antecedente ponitur aliquid pertinens ad actum animae, consequens est accipiendum non secundum quod in se est, sed secundum quod est in anima: aliud enim est esse rei in seipsa, et esse rei in anima. Ut puta, si dicam, si anima intelligit aliquid, illud est immateriale, intelligendum est quod illud est immateriale secundum quod est in intellectu, non secundum quod est in seipso. Et similiter si dicam, si Deus scivit aliquid, illud erit, consequens intelligendum est prout subest divinae scientiae, scilicet prout est in sua praesentialitate. Et sic necessarium est, sicut et antecedens".

${ }^{84}$ Henricus de Harclay, In primum librum Sententiarum, dist. 38, ed. SCHABEL (1997), pp. 175-7; WYLTON, Quaestio ordinaria utrum praedestinatus possit damnari (and IOHANNES BACONTHORPE, In primum librum Sententiarum, dist. 40), ed. SCHABEL (2011), pp. 446-8, 11. 81-126; GERARDUS BONONIENSIS, Summa theologiae, q. 25, art. 7, ed. SCHABEL (2003), pp. 183-4, 11. 358-88; ALEXANDER DE AlEXANDRIA, In primum librum Sententiarum, dist. 35, q. 3, ed. Rossini-Schabel (2005), p. 289; Petrus AureOl, Scriptum in primum librum Sententiarum, dist. 39, art. 3, ed. SCHABEL (1995), pp. 181-3, 11. 697-747; GREGORIUS ARIMINENSIS, Lectura super
} 
while the Carmelite Paul of Perugia (1344) — who seems to have known Aquinas not directly, but via Baconthorpe's copying of Wylton-found a way to interpret Aquinas favorably, beginning thus: "In this way the Holy Doctor's dictum can be understood sanely"

By the late 15th century, Thomas Aquinas, and in particular his STh, had become so important that, in his defense of Peter Auriol's doctrine, Peter de Rivo strove to interpret Aquinas' article on divine foreknowledge in his favor in the famous quarrel over future contingents that erupted at the University of Louvain in $1465^{86}$. At present Schabel is co-editing with Serena Masolini an anonymous treatise contained in a Louvain manuscript, roughly 125 pages in length, that refutes Rivo. For much of his argumentation the author, a Thomist, focuses on the proper interpretation of Aquinas, consistently rejecting Rivo's employment of the teaching doctor of the Friars Preacher. Regarding what our Thomist asserts that Aquinas posits "quasi pro regula", which he quotes verbatim, the anonymous author first wonders why Rivo employs Aquinas' rule in his favor and yet ridicules other elements of Aquinas' solution to the modal problem of reconciling foreknowledge and contingency, elements that the author explains and defends ${ }^{87}$. Later, however, our Thomist confronts 'the rule of the Doctor' in this way:

\begin{abstract}
Saving wiser judgment, I do not see how [the rule] contains the truth universally, at least as regards the intent that his example presents there, namely that, for "If the soul understands something, that is immaterial', one must understand that that is immaterial as it is in the intellect, not as it is in itself'. For in designating via 'something' a stone, this consequence is not valid: 'The soul understands something, namely a stone, therefore a stone is immaterial, incomposite, incorporeal', which predicates however apply to [a stone] according to the being that it has in the soul. For although it does follow, 'therefore the stone has immaterial, incorporeal, incomposite being in the soul', it does
\end{abstract}

primum Sententiarum, dist. 38, q. 2, art. 3, ed. TRAPP-MARCOLINO-SimON-URBAN-WendLAND (1984), pp. 300, 1. 19-302, 1. 21.

${ }^{85}$ Paulus Perusinus, In primum librum Sententiarum, q. 37, art. 4, ed. SChabel (2005), pp. 107-8, 11. 358-87: "Et isto modum dictum Sancti Doctoris potest sane intelligi [...]. Unde ponit Sanctus Doctor talem regulam [...]". ${ }^{86}$ For Peter de Rivo, see now BARTOCCI-MASOLINI-FrIEDMAN 2013.

${ }^{87}$ ANONYMus, Examen articulorum seu assertionum aliquot Petri de Rivo, art. 3, ms. Leuven, KU Leuven, Centrale Bibliotheek, Tabularium, 1635, f. 7v: "Et ponit ibi quasi pro regula 'quod quando in antecedente ponitur aliquid pertinens ad actum animae [...]'. Verum, si in hoc puncto tueatur se assertor verbis Sancti Thomae quae, sicut sonant, intentioni suae favere videntur, in quo tamen puncto tanta solemnium doctorum copia, ut supra memoravi, quorum et nomen celebre est et auctoritas ab eo discrepat, cur, quaeso, non admittit distinctionem huius propositionis: 'Omne praescitum a Deo necessario eveniet vel necessarium est esse' penes sensum compositum et divisum, sic quod in uno sensu sit falsa et in alio vera, quam tamen idem doctor admittit? Sed calumniatur assertor dictam distinctionem $[\ldots] ”$. 
not follow, "it has immaterial and incomposite being in the soul, therefore it is immaterial and incomposite 88 .

The author goes on to remark that other absurdities follow "if the aforesaid rule must be applied according to this interpretation", because if "it will be" applies to God's knowledge, then God views it as future rather than as present ${ }^{89}$. In any case, the Thomist adds, there still does not seem to be the absolute necessity that Aquinas asserts, neither in the antecedent nor in the consequent ${ }^{90}$.

So what the author does is correct the $S T h$ with the Sentences commentary, whence the Thomist derives the conclusion that the antecedent is in fact contingent and not absolutely necessary. "In this way, therefore, that doctor seems to have been ambiguous concerning whether the antecedent, 'God has known or knows that this is future', is necessary absolutely, and it seems that sometimes he thought yes, sometimes no"91. In other words, Aquinas contradicted himself, and his followers could choose one interpretation or text over another to suit their purposes, reconciling them as best they could.

\section{Conclusion}

The example of the stone, absent in Aquinas, is found in the works of such theologians as the Franciscan William of Ware (ca. 1295), Henry of Harclay, Thomas Wylton, and, via Wylton, the Carmelites John Baconthorpe and Paul of Perugia, and perhaps also Peter Auriol. Auriol

\footnotetext{
${ }^{88}$ Ibid., f. 8r: "Consequenter veniendo ad regulam Doctoris, primo de regula quam ponit, 'quando in antecedente ponitur aliquid pertinens ad actum animae' etc., non video - salvo saniori iudicio - quomodo contineat universaliter veritatem, saltem quantum ad intentionem quam praetendit exemplum suum ibi, videlicet, 'si anima intelligit aliquid, illud est immateriale, intelligendum est immateriale secundum quod est in intellectu, non secundum quod est in se ipso.' Nam designando per ly 'aliquid' lapidem, non valet consequentia: 'Anima intelligit aliquid, videlicet lapidem, ergo lapis est immaterialis, incompositus, incorporeus', quae tamen praedicata conveniunt sibi secundum esse quod habet in anima. Quamvis enim bene sequatur: 'ergo lapis habet esse immateriale, incorporeum, et incompositum in anima', non tamen sequitur: 'habet esse immateriale et incompositum in anima, ergo est immaterialis et incompositus"”.

${ }^{89}$ Ibid.: "Praeterea, si debeat praedicta regula secundum praedictam interpretationem applicari ad propositum illius consequentiae: 'Deus scivit hoc futurum esse, ergo hoc erit', sensus erit quod ly 'erit' attribuitur rei demonstratae per ly 'hoc' secundum esse quod habet in Deo, sicut in exemplo doctoris ly 'esse immateriale' attribuitur rei designatae per subiectum consequentis secundum esse quod habet in anima, quod est aliud ab esse rei in se ipsa, ut ipsemet dicit. Rei autem secundum esse quod habet in Deo non convenit ly 'erit', quia secundum tale esse non est futura seu non erit, sed est praesens et vita ab aeterno".

${ }^{90}$ Ibid.: "Esto, inquam, quod ita sit, adhuc tamen non habetur necessitas absolute dicta quam ponit doctor ille in illo antecedente, et eam salvare nititur in consequente".

${ }^{91}$ Ibid., f. 8v: "Sic ergo videtur doctor iste ambiguus extitisse de dicto antecedente: 'Deus scivit vel scit hoc futurum esse', an sit necessarium absolute, necnon et quandoque sensisse quod sic, quandoque quod non".
} 
passed it on to the Dominican John Capreolus, the author of an early 15th-century defense of Aquinas in the form of a Sentences commentary ${ }^{92}$. They seem to use it as part of their description of Aquinas' position, however, whereas our anonymous author employs it in his critique. The example is also found in Cajetan's commentary on the STh, which alerts us to the medieval contribution to the later commentary tradition. In general for this article of the STh, Cajetan deals with the critiques of John Duns Scotus, Peter Auriol, and Gregory of Rimini, but he prefaces his remarks about Aquinas' general solution based on eternity as follows:

Opponents judge this locus to be full of contradiction and error, but his followers consider Saint Thomas' doctrine to be so obscure that I have so far seen no one, whether in writing or in speech, uphold this statement, and I confess that understanding it has evaded me for perhaps fifteen years ${ }^{93}$.

There are many factors explaining the tremendous success of Thomas Aquinas and his STh. He was brilliant and prolific, arrived on the scene just as the medieval university and the Dominican Order were maturing, and belonged to the first generation of scholars with access to the full Aristotelian corpus. Early attacks on his writings rallied the Dominicans around Aquinas, whose Sentences commentary was made official teaching in 1286. Afterwards Friars Preacher composed anti-Sentences commentaries, anti-quodlibeta, and other works refuting Aquinas' detractors from outside the order, and in the 1300s and 1310s, first unofficially and then officially, the Dominicans corrected deviants within the order itself, James of Metz and Durand of Saint-Pourçain. The Dominicans successfully campaigned for the canonization of their teaching doctor, achieved in 1323. This was perhaps at the low point in Aquinas' doctrinal influence outside the order and had little immediate effect, while after 1330, aside from the rather independent Oxford Dominican Robert Holcot, the remainder of the century saw no new Dominican writings in philosophical theology of any great significance. Nevertheless, the slow growth of his cult must have made Aquinas' succinct teachings an even more attractive

92 Guillelmus DE WARIA, In primum librum Sententiarum, dist. 39, ms. Wien, Österreichische Nationalbibliothek, lat. 1424, f. 74vb; HeNRICUS DE HARCLAY, Quaestiones ordinariae, q. 3, ed. HENNINGER (2008), p. 144; THOMAS WYLTON, Quaestio ordinaria utrum praedestinatus possit damnari (and IOHANNES BACONTHORPe, In primum librum Sententiarum, dist. 40), ed. SCHABEL (2011), p. 446, 11. 89-91; PAULUS Perusinus, In primum librum Sententiarum, q. 37, art. 4, ed. Schabel (2005), p. 108, 11. 368-9; Petrus AureOLI, Scriptum in primum librum Sententiarum, dist. 39, art. 3, ed. SCHABEL (1995), p. 182, 11. 738-9; CAPREOLUS, Defensiones theologiae Thomae Aquinatis I, dist. 38, q. 1, ed. PABAN-PÈGUES (1900), p. 457a.

${ }^{93}$ Caietanus 1888, In I, q. 14, art. 13, p. 188b: “Ad has obiectiones respondendo, praemitto quod iste locus ab adversantibus iudicatur plenus contradictionis et erroris: a sequentibus autem doctrinam $\mathrm{S}$. Thomae reputatur adeo obscurus, ut neminem hactenus viderim, sive scripto sive verbo, assertive tueri hoc dictum. Et me iam annis forte quindecim fateor latuisse". 
alternative to the trendy, seemingly sophistic, ill-sounding, and presumed dangerous intellectual games that occupied faculties of theology from the 1330s to the Great Schism. As the Schism drew to a close, under the influence of Jean Gerson, Nicholas of Dinkelsbühl, and others, Thomas Aquinas achieved unprecedented importance in European theology, even in Greek translation ${ }^{94}$. Already an authority and his STh an auctoritas, Thomas Aquinas was on his way to becoming the authority in Latin Christendom. Fortunately for intellectual history, Aquinas certainly left room for interpretation and called out for commentary.

${ }^{94}$ For the above, see for example RoENSCH 1964; GERULAITIS 1967; DOD 1982; FRIEDMAN 2002; FRIEDMAN 2007; Robiglio 2008; MeWs 2009; Demetracopoulos 2011; IRIBARREN 2011; SCHABEL 2011. 


\section{BIBLIOGRAPHY}

\section{MANUSCRIPTS}

ANONYMUS. Examen articulorum seu assertionum aliquot Petri de Rivo, Leuven, KU Leuven, Centrale Bibliotheek, Tabularium, 1635, ff. 1r-25v.

GUILLELMUS DE WARIA. In primum librum Sententiarum, Wien, Österreichische Nationalbibliothek, lat. 1424.

IOHANNES DE RETZ, Collatio in exequiis magistri Conradi de Ebraco Ordinis Cysterciensis, ms. Rein, Stiftsbibliothek, Cod. 67, ff. 115v-117r.

\section{PRIMARY SOURCES}

AleXANDER De AleXANDRIA (2005). In primum librum Sententiarum, dist. 35, qq. 3-4, ed. M. ROSSINI-C. SCHABEL, "Time and Eternity among the Early Scotists. Texts on Future Contingents by Alexander of Alexandria, Radulphus Brito, and Hugh of Novocastro", Documenti e Studi sulla tradizione filosofica medievale, 16: 237-338 (pp. 284-98).

ANDREAS DE NOVO CASTRO (1954). Tractatus de conceptione Virginis gloriosae, art. 9, ed. T. SZABÒ, in Tractatus quatuor de immaculata conceptione b. Mariae Virginis, Quaracchi.

BERNARDUS LOMBARDI (2001). In primum librum Sententiarum, dist. 38, ed. C. SCHABEL-R.L. Friedman-I. BALCOYIANNOPOUlOU, "Peter of Palude and the Parisian Reaction to Durand of St. Pourçain on Foreknowledge and Future Contingents", Archivum Fratrum Praedicatorum, 71: 183300 (pp. 296-300).

CAietanus [ThOMAs De VIO] (1888). Commentaria, in Sancti Thomae Aquinatis Opera Omnia iussu impensaque Leonis XIII P.M. edita. Tomus quartus: Pars prima Summae theologiae a quaestione I ad quaestionem XLIX, Romae.

- (1895). Commentaria, in Sancti Thomae Aquinatis Opera Omnia iussu impensaque Leonis XIII P.M. edita. Tomus octavus: Secunda secundae Summae theologiae a quaestione I ad quaestionem LVI, Romae.

- (1897). Commentaria, in Sancti Thomae Aquinatis Opera Omnia iussu impensaque Leonis XIII P.M. edita. Tomus nonus: Secunda secundae Summae theologiae a quaestione LVII ad quaestionem CXXII, Romae.

- (1903). Commentaria, in Sancti Thomae Aquinatis Opera Omnia iussu impensaque Leonis XIII P.M. edita. Tomus undecimus: Tertia pars Summae theologiae a quaestione I ad quaestionem LIX, Romae.

- (1906). Commentaria, in Sancti Thomae Aquinatis Opera Omnia iussu impensaque Leonis XIII P.M. edita. Tomus duodecimus: Tertia pars Summae theologiae a quaestione LX ad quaestionem XC, Romae.

CAPreolus, I. (1900). Defensiones theologiae Thomae Aquinatis, ed. C. PABAN-T. PĖGUES, Tours (reprinted in 1967; Frankfurt), vol. II.

CARACCIOli (1999). In primum librum Sententiarum, dist. 38-40, ed. C. SCHABEL, "Landulphus Caracciolo and a Sequax on Divine Foreknowledge", Archives d'Histoire Doctrinale et Littéraire du Moyen Age, 66: 299-343.

CONRAD DE EBRACHO forthcoming. Principia I-IV, ed. M. BRÎNZEI.

Duns SCOTUS, I. (1963). Ordinatio in primum librum Sententiarum, distinctiones 26-48, ed. C. BALIĆ et al., Città del Vaticano.

DuRANDUS DE SANCTO Porciano (2001). In primum librum Sententiarum, dist. 38, q. 3, ed. C. SCHABEL-R.L. FRIEDMAN-I. BALCOYIANNOPOUlOU, "Peter of Palude and the Parisian Reaction to Durand of St. Pourçain on Foreknowledge and Future Contingents", Archivum Fratrum Praedicatorum, 71: 183-300 (pp. 250-64, 274-6). 
Gerardus BonOniEnsis (2003). Summa theologiae, q. 25, art. 7, ed. C. SCHABEL, "Early Carmelites Between Giants: Questions on Future Contingents by Gerard of Bologna and Guy Terrena", Recherches de Théologie et Philosophie médiévales, 70: 139-205 (pp. 170-86).

GREGORIUS ARIMINENSIS (1984). Lectura super primum et secundum Sententiarum. Tomus III. Super primum (dist. 19-48), ed. A.D. TrapP-V. MARCOLINO-W. SIMON-W. URBAN-V. WENDLAND, Berlin.

Guido TERRENI (2003). Quodlibet I, q. 2, art. 2, ed. C. SCHABEL, "Early Carmelites Between Giants: Questions on Future Contingents by Gerard of Bologna and Guy Terrena", Recherches de Théologie et Philosophie médiévales, 70: 139-205 (pp. 187-92).

HENRICUS DE HARCLAY (1997). In primum librum Sententiarum, dist. 38-39, ed. C. SCHABEL, "Aufredo Gonteri Brito secundum Henry of Harclay on Divine Foreknowledge and Future Contingents", Disputatio, 2: 159-96.

- (2008), Quaestiones ordinariae, ed. M.G. HENNINGER, Henry of Harclay, Ordinary Questions I-XIV, Oxford.

HeRvaeus Natalis (PSEUdO-?) (2014). Correctorium Iacobi Metensis, I Sententiarum, dist. 38, ed. C. SCHABEL, "Dominican Anti-Thomism: James of Metz's Question on Divine Foreknowledge, with a Rebuttal from Hervaeus Natalis' Correctorium Iacobi Metensis", Przeglad Tomistyczny, 20: 3572 .

IACOBUS LAUSANENSIS (2001). In primum librum Sententiarum, redactio B, d. 38, ed. C. SCHABEL-R. L. FRIEDMAN-I. BALCOYIANNOPOUlOU, "Peter of Palude and the Parisian Reaction to Durand of St. Pourçain on Foreknowledge and Future Contingents", Archivum Fratrum Praedicatorum, 71: 183-300 (pp. 277-89).

IACOBUS MeTENSIS (2014). In primum librum Sententiarum, d. 38, ed. C. SCHABEL, "Dominican AntiThomism: James of Metz's Question on Divine Foreknowledge, with a Rebuttal from Hervaeus Natalis' Correctorium Iacobi Metensis", Przeglad Tomistyczny, 20, 35-72.

IOHANNES DE POLLIACO (2011). Quaestiones ordinariae, q. 1, ed. C. SCHABEL, "Parisian Secular Masters on Divine Foreknowledge and Future Contingents in the Early Fourteenth Century, Part I: John of Pouilly's Quaestio Ordinaria I", Recherches de Théologie et Philosophie médiévales, 78: 161-219 (pp. 166-219).

KNAPWELL, R. (1927). Les premières polémiques thomistes: I.-Le correctorium corruptorii 'Quare', ed. P. GLORIEUX, Kain.

MACCLESFIELD, G. (?) (1954). Le correctorium corruptorii 'Quaestione'. Texte anonyme du ms. Merton 267, ed. J.-P. MULLER, Roma.

ORFORD, R. (1956). Les premières polémiques thomistes: I.-Le correctorium corruptorii 'Sciendum', ed. P. GLORIEUX, Paris.

PAUlus PeRUSINUS (2005). In primum librum Sententiarum, q. 37, ed. C. SchaBel, "The Sentences Commentary of Paul of Perugia, O.Carm. With an Edition of His Question on Divine Foreknowledge", Recherches de Théologie et Philosophie médiévales, 72: 54-112 (pp. 90-112).

Petrus DE Alliaco. "Sermo coram Papa Clemente VII Avenione habitus", "Propositio facta in consistorio contra M. Ioannem de Montesono", "Tractatus ex parte universitatis studii Parisiensis pro causa fidei contra quemdam fratrem Johannem de Montesono Ordinis Praed. editus a Petro de Alliaco Episcopo et Cardinali Cameracensi circa annum 1388", in C. Du Plessis D'ARGENTRÉ (1728), Collectio iudiciorum de novis erroribus, Parisiis, vol. I, pars 2, pp. 66-129 (66-9; 69-74; 75-129).

- . "Sermo coram Papa Clemente VII Avenione habitus", "Propositio facta in consistorio contra M. Joannem de Montesono", "Apologia Facultatis Theologiae Parisiensis circa damnationem Joannis de Montesono", in JOANNES GERSONIUS (1706). Opera Omnia, ed. E. DU PIN, Antwerpiae, vol. I, coll. 697-722 (697-702; 702-9; 710-22).

Petrus De Alvernia (2015). Quodlibet IV, q. 2, ed. SCHABel (2014), "Peter of Auvergne's Quodlibetal Questions on Divine Knowledge", in Peter of Auvergne, University Master of the 13th Century, ed. C. FlÜELER-L. LANZA-M. TOSTE, Berlin-München-Boston: 355-90 (pp. 376-83).

Petrus Aureoli (1995). Scriptum in primum librum Sententiarum, dd. 38-39, ed. C. SCHABEL, "Peter Aureol on Divine Foreknowledge and Future Contingents: Scriptum in Primum Librum 
Sententiarum, distinctions 38-39", Cahiers de l'Institute du moyen-âge grec et latin, 65: 63-212 (pp. 87-212).

Petrus De PALUde (2001). In primum librum Sententiarum, d. 38, q. 3, ed. C. SCHABeL-R.L. FRIEDMAN-I. BALCOYIANNOPOUlOU, "Peter of Palude and the Parisian Reaction to Durand of St. Pourçain on Foreknowledge and Future Contingents", Archivum Fratrum Praedicatorum, 71: 183300 (pp. 250-73).

QUIDORT PARISIENSIS, I. (1941). Le correctorium corruptorii 'Circa' de Jean Quidort of Paris, ed. J.P. MULLER, Roma.

Wylton, T. (2011). Quaestio ordinaria utrum praedestinatus possit damnari (and IOHANNES BACONTHORPE, In primum librum Sententiarum, dist. 40), ed. C. SCHABEL, "Parisian Secular Masters on Divine Foreknowledge and Future Contingents in the Early Fourteenth Century, Part II: Thomas Wylton's Quaestio ordinaria 'Utrum praedestinatus possit damnari'”, Recherches de Théologie et Philosophie médiévales, 78: $417-79$ (pp. 443-69 and 470-9).

\section{SECONDARY LITERATURE}

Alliney, G. (1999). "De centro in circumferentia. Metafore spaziali del rapporto tempo-eternità in Tomasso d'Aquino", Archives d'histoire doctrinale et littéraire du moyen âge, 66: 89-120.

BARTOCCI, B.-MASOLINI, S.-FrIEDMAN, R.L. (2013). "Reading Aristotle at the University of Louvain in the Fifteenth Century: A First Survey of Petrus de Rivo's Commentaries on Aristotle (I)", Bulletin de philosophie médiévale, 55: 133-76.

BRÎNZEI, M-SCHABEL, C (2018). "Les cisterciens et l'université. Le cas du commentaire des Sentences de Conrad d'Ebrach ( $\uparrow 1399)$ ", in Les cisterciens et leurs bibliothèques, ed. A.-M. TURCANVERKERK-D. STUTZMANN-T. FALMAGNE-P. GANDIL, Turnhout: 453-86.

DECKER, B. (1967). Die Gotteslehre des Jacob von Metz. Untersuchungen zur Dominikanertheologie zu Beginn des 14. Jahrhunderts, Münster.

Demetracopoulos, J.A. (2011). "Thomism, Byzantine", in Encyclopedia of Medieval Philosophy. Philosophy Between 500 and 1500, ed. H. LAGERLUND, Dordrecht et al.: 1308b-1311a.

Denifle, H.-Chatelain, A. (ed.) (1894). Chartularium Universitatis Parisiensis, vol. III, Paris.

DoD, B.G. (1982). "Aristoteles Latinus", in The Cambridge History of Later Medieval Philosophy, ed. N. KRETZMANN-A. KENNY-J. PINBORG, Cambridge: 43-79.

DuBA, W.O. (2017). The Forge of Doctrine. The Academic Year 1330-31 and the Rise of Scotism at the University of Paris, Turnhout.

EHRLE, F. (1932). I più antichi statuti della facoltà teologica dell'Università di Bologna, Bologna.

Evans, G.R. (ed.) (2002). Mediaeval Commentaries on the 'Sentences' of Peter Lombard. Volume I, Leiden-Boston-Köln.

FRIEDMAN, R.L. (2002). "The Sentences Commentary, 1250-1320. General Trends, the Impact of the Religious Orders, and the Test Case of Predestination", in Mediaeval Commentaries on the 'Sentences' of Peter Lombard. Volume I, ed. G.R. Evans, Leiden-Boston-Köln: 41-128.

- (2007). "Dominican Quodlibetal Literature, ca. 1260-1330", in Theological Quodlibeta in the Middle Ages. The Fourteenth Century, ed. C. SCHABEL, Leiden-Boston: 401-91.

- (2013). Intellectual Traditions at the Medieval University. The Use of Philosophical Psychology among the Franciscans and Dominicans, 1250-1350, 2 vols., Leiden-Boston.

GAUTHIER, R.-A. (1952). "Les Articuli in quibus frater Thomas melius in Summa quam in Scriptis", Recherches de théologie ancienne et médievale, 19: 271-326.

GERULAITIS, L.V. (1967). "The Canonization of Saint Thomas Aquinas", Vivarium, 5: 25-46.

GLORIEUX, P. (1966). "Pierre d'Ailly et Saint Thomas", in Littérature et religion: mélanges offerts à Monsieur Joseph Coppin, Lille: 45-54.

Golubovich, G. (1919). Biblioteca bio-bibliografica della Terra Santa e dell'Oriente francescano, vol. III, Quaracchi.

GroblicKI, J. (1938). De scientia Dei futurorum contingentium secundum S. Thomam eiusque primos sequaces, Kraków. 
HISSETTE, R. (1977). Enquête sur les 219 articles condamnés à Paris le 7 mars 1277, Louvain.

HOENEN, M.J.F.M. (1993). Marsilius of Inghen. Divine Knowledge in Late Medieval Thought, Leiden.

- (2012). "How the Thomists in Cologne Saved Aristotle: The Debate over the Eternity of the World in the Late-Medieval Period", in Philosophy and Theology in the 'Studia' of the Religious Orders and at Papal and Royal Courts, ed. K. EMERY-W.J. COURTENAY-S.M. METZGER, Turnhout: 181217.

IrIBARREN, I. (2011). "Thomism", in Encyclopedia of Medieval Philosophy. Philosophy Between 500 and 1500, ed. H. LAGERLUND, Dordrecht et al.: 1302a-1308b.

Kelly, J.F. (1976). "The Place of Pierre d'Ailly in the Development of Medieval Theological Sources and Censures", Studies in Medieval Culture, 6-7: 141-50.

KRUPA, P. (2005). "La lettre en défense de Saint Thomas d'Aquin de Jean de Monzon", Archivum Franciscanum Historicum, 98: 633-47.

- (2013). Une grave querelle. L'Université de Paris, les Mendiants et la conception immaculée de la Vierge (1387-1390), Warszawa.

LAMY, M. (2000). L'immaculée conception: étapes et enjeux d'une controverse au Moyen Âge, XII $X V^{e}$ siècles, Paris.

LAUTERER, K. (1961). "Johannes von Retz OESA, Collatio in Exequiis Mag. Conradi de Ebraco. Ein Nachruf für Konrad von Ebrach", Cistercienser-Chronik, 68: 23-40.

- (1962). Konrad von Ebrach S.O.CIST (†1399): Lebenslauf und Schriftum, Roma.

MANDONNET, P. (1913). "Premiers travaux de polémique thomiste", Revue des sciences philosophique et théologique, 7: 46-70.

MARCOLINO, V. (1990). "Das Nachwirken der Lehre Hugolins", in Schwerpunkte und Wirkungen des Sentenzenkommentars Hugolins von Orvieto O.E.S.A., ed. W. ECKERMANN, Würzburg: 295-481.

Mews, C. J. (2009). "Remembering St. Thomas in the Fourteenth Century: Between Theory and Practice", Przeglad Tomistyczny, 15: 77-91.

MülleR, S. (2005). "Pierre d'Ailly und die 'Richtige' Thomas-Interpretation: theologischhermeneutische Prinzipien als Gundlage des Wegestreits", Traditio, 60: 339-68.

OUY G. (1963). "La plus ancienne œuvre retrouvée de Jean Gerson: le brouillon inachevé d'un traité contre Juan de Monzon (1389-90)", Romania, 83: 433-92.

RoBiglio, A.A. (2008). La sopravvivenza e la gloria. Appunti sulla formazione della prima scuola tomista (sec. XIV), Bologna.

RoBIN-FABRE, A.-S. (2013). 'Contra Thomam': un aperçu de l'antithomisme à la fin du XIII siècle et au début du XIVe, $\mathrm{PhD}$ dissertation, Université de Paris IV-Sorbonne.

RoEnSCH, F. J. (1964). Early Thomistic School, Dubuque, IA.

Rosemann, P.W. (ed.) (2010). Mediaeval Commentaries on the 'Sentences' of Peter Lombard. Volume 2, Leiden-Boston.

SCHABEL, C. (ed.) (2007). Theological Quodlibeta in the Middle Ages. The Fourteenth Century, LeidenBoston.

- (2011). "Reshaping the Genre: Literary Trends in Philosophical Theology in the Fourteenth Century", in Crossing Boundaries at Medieval Universities, ed. S.E. YOUNG, Leiden - Boston: 5184.

- (2014). "Cistercian University Theologians on the Filioque", Archa Verbi 11: 124-89.

SCHABEL, C.-BRÎNZEI, M.-MAGA, M. (2015). "A Golden Age of Theology at Prague: Prague Sentences Commentaries, ca. 1375-1385, with a Redating of the Arrival of Wycliffism in Bohemia", Acta Universitatis Carolinae-Historia Universitatis Carolinae Pragensis, 55: 19-39.

SCHACHENMAYR, A. V. (2012). "Das Kolleg Sankt Nikolaus an der Universität Wien, ein Studienhaus der Cistercienser", in Die regulierten Kollegien im Europa des Mittelalters und der Renaissance, ed. A. SOHN-J. VERGER, Bochum: 151-9.

SHANK, M.H. (1988). 'Unless You Believe, You Shall Not Understand'. Logic, University and Society in Late Medieval Vienna, Princeton, NJ.

STINSON, T.L. (2012). "Illumination and Interpretation: The Depiction and Reception of Faus Semblant in Roman de la Rose Manuscripts", Speculum, 87: 469-98. 
TABER, D. jr. (1990). "Pierre d'Ailly and the Teaching Authority of the Theologian", Church History, 59: $163-74$.

TORRELL, J.-P. (1993). Initiation à saint Thomas d'Aquin, Fribourg.

TRAPP, D. (1956). "Augustinian Theology of the 14th Century. Notes on Editions, Marginalia, Opinions and Book-Lore", Augustiniana, 6: 146-274.

URBAIN V (1954-1985). Lettres communes, 12 vols., ed. P. GASNAULT-M.H. LAURENT-M. HAYEZA.-M. HAYEZ, Paris.

ZuMKeller, A. (1948). Dionysius de Montina, ein neuentdeckter Augustinertheologe des Spätmittelalters, Würzburg.

— (1949). "Der Zisterziensertheologe Konrad von Ebrach (†1399) im Kampf um Thomas von Aquin", Cistercienser-Chronik, 56: 1-24. 